\title{
Stable isotopes in deep-sea living (stained) foraminifera from the Mozambique Channel (eastern Africa): multispecies signatures and paleoenvironmental application
}

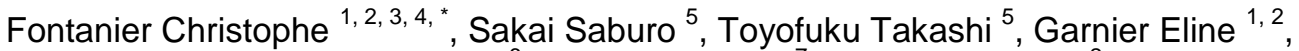 \\ Brandily Christophe ${ }^{6}$, Eugene Thibaut ${ }^{7}$, Deflandre Bruno ${ }^{2}$
}

${ }^{1}$ Ifremer, Laboratoire Geodynamique et Enregistements Sedimentaires, Centre de BrestTechnopôle de Brest-IroisePlouzané, France

${ }^{2}$ Université de BordeauxLaboratoire Environnements et Paléo-environnements Océaniques et Continentaux, UMR 5805Pessac, France

${ }^{3}$ FORAM, Foraminiferal Study GroupVillevêque, France

${ }^{4}$ Université d'AngersAngers, France

5 Japan Agency for Marine Earth Science and TechnologyYokosuka, Japan

${ }^{6}$ Ifremer, Laboratoire Environnements Profonds, Centre de BrestTechnopôle de Brest-IroisePlouzané, France

7 Ifremer, Service Cartographie, Traitement de Données et Instrumentation, Centre de BrestTechnopôle de Brest-IroisePlouzané, France

* Corresponding author : Christophe Fontanier, email address : christophe.fontanier@ifremer.fr ; c.fontanier@foram.eu.com

\begin{abstract}
:
Oxygen and carbon isotopes $(\delta 180$ and $\delta 13 C)$ have been investigated in carbonate tests of deep-sea foraminifera living in the Mozambique Channel (eastern Africa) to understand how environmental constraints (e.g., organic matter, oxygenation) control the intra- and interspecific variability of isotopic signatures. 197 living individuals, including eight different species, from various microhabitats within the sediment were sorted from sediment samples gathered at two stations on the Malagasy upper slope. Results show that the $\delta 180$ values of foraminiferal taxa were not controlled by microhabitat pattern. They presented tremendous and intriguing intraspecific variability that is not explained by the classical ontogenetic effect. The $\delta 13 \mathrm{C}$ values of infaunal foraminiferal taxa do not show a 1:1 relationship with the bottom water $\delta 13 \mathrm{C}$ DIC and do not present a constant offset from it; instead, they appear to be mainly controlled by a microhabitat effect. The lower $\delta 13 \mathrm{C}$ values of shallow, intermediate, and deep infaunal taxa at the deeper station compared to those seen at the shallower station reflect the enhanced exportation of sedimentary organic matter at the sediment-water interface, and its related mineralization within the upper sediments. The $\Delta \delta 13 \mathrm{C}$ between shallow/very shallow infaunal species (i.e., Hoeglundina elegans, Uvigerina hispida) and intermediate/deep infaunal species (i.e., Melonis barleeanus, Globobulimina barbata) permits insight into (1) the exportation of organic matter to the seafloor and (2) the various degradation pathways for organic detritus in the benthic environments off NW Madagascar.
\end{abstract}


Keywords: Oxygen and carbon isotopes, Deep-sea foraminifera, Organic matter, Oxygenation, Microhabitat 


\section{Introduction}

Numerous studies have been performed for the last four decades about the stable isotopes of deep-sea benthic foraminifera (Woodruff et al., 1980; Grossman, 1984a, 1984b, 1987; Dunbar and Wefer, 1984; Mackensen and Douglas, 1989; McCorkle et al., 1990, 1997; Mackensen et al., 1993, 2000, 2006; Sen Gupta and Aharon, 1994; McCorkle et Keigwin, 1994; Rathburn et al., 1996, 2000, 2003; Sen Gupta et al., 1997; Corliss et al., 2002, 2006; Torres et al., 2003; Mackensen and Licari, 2004; Schmiedl et al., 2004; Holsten et al., 2004; Filipsson et al., 2004; Hill et al., 2004; Panieri, 2006; Fontanier et al., 2006, 2008, 2014; Eberwein and Mackensen, 2006; Schmiedl and Mackensen, 2006; Mackensen, 2008; Basak et al., 2009; Staines-Urías and Douglas, 2009; Martin et al., 2010; Schumacher et al., 2010; Ishimura et al., 2012; Mackensen, 2013; Theodor et al., 2016). On this basis, the $\delta^{18} \mathrm{O}$ of benthic foraminifera is generally close to equilibrium with the $\delta^{18} \mathrm{O}$ of bottom water following a temperature-dependant fractionation. That being said, foraminiferal taxa present intra- and interspecific offsets that are related to other cryptic fractionation effects (e.g., vital effects). Concerning carbon isotopes, it is commonly accepted that the carbon isotope signature of infaunal benthic foraminifera is strongly influenced by ambient pore water $\delta^{13} \mathrm{C}$. Usually, the profile of ambient pore water $\delta^{13} \mathrm{C}$ shows a rapid isotopic depletion with depth in the sediment, caused by the release of ${ }^{13} \mathrm{C}$-depleted $\mathrm{CO}_{2}$ related to the decomposition of sedimentary organic matter (Grossman, 1984a, 1984b, 1987; McCorkle et al., 1985). Foraminiferal taxa calcifying in the pore water of the sediment interval in which they preferentially live, seem therefore mirror this depletion, and show a so-called "microhabitat effect". Moreover, intraspecific differences related to ontogenetic stage and to reproduction mode (asexual/sexual) have been documented (e.g., Dunbar and Wefer, 1984; Schmiedl et al., 2004; Staines-Urías and Douglas, 2009; Schumacher et al., 2010; Theodor et al., 2016). Moreover, the concentration of the various carbonate species may have a significant impact 
on the fractionation of carbon and oxygen isotopes (e.g., Zeebe and Wolf-Gladrow, 2001). Finally, all available evidences show that the interpretation of carbon isotopes in benthic foraminiferal tests in relation with the chemical properties of bottom and interstitial waters requires an exhaustive knowledge of the ecology and the biology of the investigated taxa (depth of calcification, food preferences, reproduction mode, ontogenetic cycle, internal $\mathrm{pH}$ regulation, test texture) and an understanding of geochemical processes affecting the carbonate and stable isotope chemistry of bottom and pore waters (e.g. McCorkle et al., 1990, 1997; Mackensen et al., 1993, 2000, 2006; McCorkle and Keigwin, 1994; Rathburn et al., 1996, 2000, 2003; Corliss et al., 2002; Mackensen and Licari, 2004; Schmiedl et al., 2004; Holsten et al., 2004; Fontanier et al., 2006, 2008, 2014; Eberwein and Mackensen, 2006; Mackensen, 2008; Basak et al., 2009; Staines-Urías and Douglas, 2009; Schumacher et al., 2010; Theodor et al., 2016).

This work deals with the oxygen and carbon isotopes in carbonate tests of live benthic foraminifera collected at two Malagasy upper-slope stations (respectively 530- and 780-m deep) in the Mozambique Channel (Eastern Africa; Fig. 1). Both stations were sampled during the PAMELA-MOZ1 cruise aboard the R/V L'Atalante (Genavir-Ifremer). Eight benthic foraminiferal taxa belonging to the $>125 \mu \mathrm{m}$ size fraction are investigated: Bolivina alata, Bulimina inflata, Bulimina marginata, Globobulimina barbata, Hoeglundina elegans, Melonis barleeanus, Pullenia bulloides and Uvigerina hispida. At both stations, foraminiferal standing stocks, composition and microhabitats are controlled by the sedimentary organic matter and the dissolved oxygen concentration at and below the sediment water interface (Fontanier et al., 2016). Together, these factors define intermediate and deep infaunal microhabitats, where some highly specialized taxa are capable to thrive (e.g. Melonis barleeanus, Globobulimina barbata). The higher foraminiferal standing stocks are observed at the 780-m deep station, where peculiar sedimentary facies of labile organic matter focusing 
are recorded with an organic-carbon content $>2.0 \%$ Dry Weight. This station is obviously under the influence of sedimentary inputs related to Mahavavy river (Fontanier et al., 2016; submitted). Bolivina alata, Bulimina marginata, Haplophragmoides bradyi and Nouria compressa are relevant bio-indicators of enhanced burial of organic matter at this site (i.e., eutrophic settings). Uvigerina hispida is dominant at the 530-m deep station where more mesotrophic environmental settings prevail. Interestingly, living species (B. marginata, $U$. hispida, H. elegans, M. barleeanus), which are characterized by different microhabitat, are shared by both stations. Moreover, many long cores (küllenberg-type) were also collected in this study area (Olu, 2014). These are expected to propose fairly promising sedimentary archives where centennial/millennial variability of environmental parameters (organic carbon supply, bottom water oxygenation, sedimentary inputs) in relation to past climate changes (e.g. monsoon, glacial-interglacial transition) can be assessed. Therefore a thorough understanding of isotopic signatures $\left(\delta^{18} \mathrm{O}, \delta^{13} \mathrm{C}\right)$ in modern benthic foraminifera is essential to initiate any kind of paleo-environmental investigation.

The present study aims to compare the benthic foraminiferal isotopic signatures $\left(\delta^{18} \mathrm{O}\right.$, $\delta^{13} \mathrm{C}$ ) with physico-chemical and biogeochemical properties (temperature, oxygenation, sedimentary organic matter) of bottom and sediment pore waters on the Malagasy upper slope (Fig. 1; Tables 1 and 2). The degradation of sedimentary organic matter and its effect on carbonate geochemistry are supposed to have a major impact on the $\delta^{13} \mathrm{C}$ signal of the Dissolved Inorganic Carbon (DIC) of bottom and interstitial waters, and should provoke consistent downslope changes of the $\delta^{13} \mathrm{C}$ isotopic signature of benthic foraminifera presenting different microhabitats (Ishimura et al., 2012),. In addition, we expect an overall depletion of benthic foraminiferal $\delta^{13} \mathrm{C}$ values for all individuals thriving at the $780-\mathrm{m}$ deep station, where sedimentary organic matter (OM) focuses and oxygen penetration depth is 
limited by enhanced OM mineralisation. At the light of our results, we aim to propose paleoproductivity proxies based on multispecies $\delta^{13} \mathrm{C}$ signatures.

\section{Material and Methods}

\subsection{Study area}

The two study sites were sampled during the PAMELA-MOZ1 cruise aboard the R/V L'Atalante (Genavir-Ifremer) (Fig. 1; Table 1) (Olu, 2014). This cruise took place in the Mozambique Channel off Mozambique and Madagascar (eastern Africa) in October 2014. One major current dominates surface waters in this region: the Mozambique Current, which is mainly related to the South Equatorial Current originating from the central Indian Ocean (Schouten et al., 2003; Ridderinkhof et al., 2010; Ullgren et al., 2012; Ternon et al., 2014). The Mozambique Current is expressed in complex dipoles of anti-cyclonic and cyclonic eddies that flow southward through the western Mozambique Channel, and in turn generate partly the Agulhas Current. Those eddies produce hydrological fronts, divergence zones and upwellings, which affect surface and subsurface waters (Ridderinkhof and De Ruitjer, 2003). Below, the South Indian Central Water (SICW), which corresponds to the permanent thermocline (temperature between 8 and $13^{\circ} \mathrm{C}$, salinity between 34.8 and $35.2 \mathrm{psu}$ ), occupies depth range between 200 and $600 \mathrm{~m}$ depth (Ullgren et al., 2012). Intermediate waters are characterized by a complex mixture between oxygen-depleted and salty Red Sea Water (RSW; salinity $>34.7 \mathrm{psu}$ ) from the north and fresh Antarctic Intermediate Water (AAIW; Salinity < $34.5 \mathrm{psu}$ ) from the south (Roman and Lutjeharms, 2009; Ullgren et al., 2012). Regarding primary production, the Mozambique Channel is considered as a mesotrophic basin with values ranging between 100 and $150 \mathrm{~g} \mathrm{C} / \mathrm{m}^{2} / \mathrm{yr}$ (Antoine et al., 1996). Large phytoplankton blooms (mainly cyanobacteria and coccolithophorids) are recorded in austral 
summer (i.e., rainy period), with a linkage to coastal upwelling, precipitation along the Madagascar and Mozambique coasts, light penetration and local mesoscale circulation features in relation to eddies (Machu and Garçon, 2001; Tew-Kai and Marsac, 2009; Raj et al., 2010).

In this study, both stations are located on upper slope off north-western Madagascar (Fig. 1). The so-called "Betsiboka slope" station (i.e., multi-corer deployments MTB-1 and MTB-2; 528-m depth) is located on the upper slope at $558 \mathrm{~m}$ depth, $50 \mathrm{~km}$ off the Betsiboka river mouth (Fig. 1; Table 1). It is bathed by SCIW. The "Mahavavy slope" station (i.e., multi-corer deployments MTB-6 and MTB-7; 780-m depth) is located $\sim 30 \mathrm{~km}$ southwestward from the previous station - but only $30 \mathrm{~km}$ far from the Mahavavy river mouth (Fig. 1). This station is bathed by an intermediate water mass consisting of a mixture between RSW and AAIW. It is noteworthy that the Betsiboka River is the main river of Madagascar in terms of length, watershed, as well as discharge (Berthois and Crosnier, 1965). It is characterized by a $20 \mathrm{~km}$ long estuary. Because of modern deforestation in its catchment basin, the Betsiboka estuary has evolved to a high sedimentation area and is characterised by one of the world's fastest coastal dynamics (Lebigre, 1990; Ralison et al., 2008). The Mahavavy is also an important Malagasy river, which differs from the Betsiboka by its triangle-shape delta opened to the ocean.

\subsection{Sediment coring}

Sediment samples were collected with a Barnett-type multi-corer equipped with eight Plexiglas tubes (96-mm internal diameter; Barnett et al., 1984). The multi-corer allowed sampling of the upper decimetre of the sediment column, the overlying bottom waters, and a comparatively undisturbed sediment-water interface. It was deployed twice at each station (Table 1). Two duplicate cores per station (gathered from the same multi-corer deployment) 
were processed for foraminiferal investigation. On board ship, each core was sliced horizontally every $0.5 \mathrm{~cm}$ from the sediment-water interface to $4-\mathrm{cm}$ depth, every $1-\mathrm{cm}$ between $4-10-\mathrm{cm}$ depth. The corresponding samples were transferred into $500-\mathrm{cm}^{3}$ bottles, which were filled with 95\% ethanol containing $2 \mathrm{~g} / \mathrm{L}$ Rose Bengal stain, commonly used to identify live foraminifera (Walton, 1952; Murray \& Bowser, 2000). All samples were gently shaken for several minutes to obtain a homogeneous mixture. At the laboratory (3 months after the cruise), samples were sieved through both 63 and $125-\mu \mathrm{m}$ mesh screens, and the sieve residues were stored in $95 \%$ ethanol. Ecological patterns of living (stained) foraminiferal faunas belonging to the $>125-\mu \mathrm{m}$ size fraction and environmental parameters (pore-water dissolved oxygen, dissolved oxygen in bottom water, grain-size, sedimentary organic matter) were discussed in Fontanier et al. (2016) (Tables 1 and 2). All stable isotopic analyses presented in this paper were performed on living (stained) foraminifera (Table 3). Microhabitat patterns of species selected for isotope measurement are pictured in Figures 3ab.

\subsection{Stable Isotope measurements}

Isotopic measurements $(\mathrm{n}=120)$ were performed on 197 individuals belonging to 8 dominant taxa of living (stained) foraminifera: Bolivina alata, Bulimina inflata, Bulimina marginata, Globobulimina barbata, Hoeglundina elegans, Melonis barleeanus, Pullenia bulloides and Uvigerina hispida. All individuals are considered autochthonous and alive at the sampling time. Table 3 gives the numbers of specimens analyzed and the stable isotopic composition as determined with a GV IsoPrime mass spectrometer using an automated carbonate preparation system (IsoPrime Multiprep) at Japan Agency for Marine-Earth Science. Each analysis represents 1-5 individuals of about $>125 \mu \mathrm{m}$ in size cleaned in an ultrasonic bath (Table 3). Reaction temperature was $90^{\circ} \mathrm{C}$ in the $\mathrm{GV}$ IsoPrime mass 
spectrometer. All values are given in $\delta$-notation versus VPDB (Table 3). The precision of the measurements at $1 \sigma$ was better than $\pm 0.06 \%$ o for oxygen and carbon isotopes. It is worthy to note that we have not discriminated any size sub-fraction within the $>125 \mu \mathrm{m}$ size class. Only for Bolivina alata, Bulimina marginata and Uvigerina hispida, we made a qualitative (and relative) differentiation between samples containing small-sized specimens (= preadults) and samples bearing moderate-to-large-sized individuals (= adults) (Table 3).

Two approaches were used to obtain the $\delta^{13} \mathrm{C}$ of dissolved inorganic carbon in bottom water $\left(\delta^{13} \mathrm{C}_{\mathrm{DIC}}\right)$. First, Kroopnick's equation was used to link apparent oxygen utilization in bottom water (AOU) with $\delta^{13} \mathrm{C}_{\text {DIC }}$ (Kroopnick, 1985) (Table 1):

$$
\delta^{13} C_{D I C}=1.54-(0.0074 \times A O U)
$$

where AOU is defined as the difference between the saturation dissolved oxygen concentration in bottom water $\left(\mathrm{BWO}_{\text {sat }}\right)$ and the measured dissolved oxygen concentration $\left(\mathrm{BWO}_{\text {meas }}\right)$

$$
A O U=B W O_{\text {sat }}-B W O_{\text {meas }}
$$

The saturation dissolved oxygen concentration in bottom water $\left(\mathrm{BWO}_{\text {sat }}\right)$ is determined by a ICES/CIEM calculator available on http://ocean.ices.dk/Tools/Calculator.aspx (Table 1). This enable to estimate $\delta^{13} \mathrm{C}_{\mathrm{DIC}}$ values between $0.6 \%$ at the Mahavavy slope station and $0.9 \%$ at the Betsiboka slope station (Table 1).

Alternatively, we gathered $\delta^{13} \mathrm{C}_{\mathrm{DIC}}$ values from the World Ocean Database 2009 (WOD09 files in http://www.nodc.noaa.gov/OC5/WOD/pr_wod.html). We used a $\delta^{13} \mathrm{C}_{\text {DIC }}$ vertical profile in the water column, which was performed at a station located in the Comoro Basin in January 1996 (station ID: 4175, Latitude $-11^{\circ} 42.0^{\prime} \mathrm{N}$; Longitude 48³4.9’'E) (Fig. 2). 
This second approach enables to get $\delta^{13} \mathrm{C}_{\mathrm{DIC}}$ values between $0.7 \%$ at the Mahavavy slope station and $1.1 \%$ at the Betsiboka slope station, what matches relatively well with the previous method. Regarding the oxygen isotopic composition of bottom water relative to SMOW $\left(\delta^{18} \mathrm{Ow}\right)$, we could not obtain any values from previous publications and cruises. Therefore, we could not appreciate the $\delta^{18} \mathrm{O}$ of calcite in equilibrium with the bottom water for a given temperature.

\section{Results}

We present in Figure 4 all isotope data (either $\delta^{18} \mathrm{O}$ or $\delta^{13} \mathrm{C}$ ) related to both duplicate cores collected at each station. When possible (i.e., same species occurring in the same sediment interval for a single or for both duplicate cores), we calculated mean $\delta^{18} \mathrm{O}$ and $\delta^{13} \mathrm{C}$ values for each taxon (i.e. so-called "specific mean value").

\subsection{Benthic foraminiferal $\delta^{18} O$ values at the Betsiboka slope station}

The $\delta^{18} \mathrm{O}$ values range between $+1.65 \%$ o $\pm 0.36 \%$ and $+3.65 \%$ o $\pm 1.44 \%$ (Fig. 4 ). The heaviest signature is recorded for Uvigerina hispida, which was picked in the $0-0.5 \mathrm{~cm}$ interval. This calcitic taxon occupies a shallow infaunal microhabitat (Fig. 3a). Hoeglundina elegans is a shallow infaunal aragonitic species, which presents a mean signature of $+3.55 \%$ o $\pm 0.81 \%$, very close to previous taxon. Bulimina marginata $\delta^{18} \mathrm{O}$ value is $+2.73 \%$ o $\pm 0.88 \%$. Melonis barleeanus and Globobulimina barbata, which thrive in intermediate and in deep infaunal microhabitats respectively, present values ranging between $+1.65 \%$ o $\pm 0.36 \%$ and $+2.27 \%$ o $\pm 0.40 \%$ o (Figs. 4 and $3 a$ ).

\subsection{Benthic foraminiferal $\delta^{13}$ C values at the Betsiboka slope station}


The $\delta^{13} \mathrm{C}$ values ranges between $-1.89 \%$ $\pm 0.13 \%$ and $+1.42 \%$ $\pm 1.09 \%$ (Fig. 4 ). Regarding shallow infaunal species picked from the $0-0.5 \mathrm{~cm}$ interval, a strong interspecific variability exists with the most depleted $\delta^{13} \mathrm{C}$ values recorded for Uvigerina hispida and Bulimina marginata $\left(-0.18 \%\right.$ and $+0.04 \%$, respectively) compared to the heaviest $\delta^{13} \mathrm{C}$ signature $\left(+1.42 \%_{0} \pm 1.09 \%\right.$ ) recorded by Hoeglundina elegans (Figs. 3a and 4). Note that $H$. elegans $\delta^{13} \mathrm{C}$ is the closest to the $\delta^{13} \mathrm{C}$ of dissolved inorganic carbon in bottom water $\left(\delta^{13} \mathrm{C}_{\mathrm{DIC}}\right)$ with values comprised between $+0.9 \%$ and $+1.1 \%$. The lowest value is noticeably recorded for the deep infaunal Globobulimina barbata picked in the $3-5 \mathrm{~cm}$ interval. G. barbata recovered from the $1.5-4 \mathrm{~cm}$ interval presents also a strong depletion $(-1.81 \% \mathrm{o} \pm 0.15 \% \mathrm{c})$. The $\delta^{13} \mathrm{C}$ values recorded for the intermediate infaunal Melonis barleeanus are slightly heavier compared to G. barbata.

\subsection{Benthic foraminiferal $\delta^{18} \mathrm{O}$ values at the Mahavavy slope station}

The $\delta^{18} \mathrm{O}$ values range between $+0.52 \%$ and $+4.18 \%$ o $\pm 0.21 \%$ (Fig. 4 ). The heaviest signature is recorded by Bolivina alata in the $0-0.5 \mathrm{~cm}$ interval. Its $\delta^{18} \mathrm{O}$ decreases gradually with sediment depth to reach a value of $+2.06 \% \pm 0.29 \%$ in the $1.5-2 \mathrm{~cm}$ interval. The $\delta^{18} \mathrm{O}$ values of Bulimina marginata range between $+2.76 \%$ o $\pm 1.05 \%$ and $+3.25 \%$ o $\pm 0.45 \%$. The $\delta^{18} \mathrm{O}$ values of Hoeglundina elegans and Uvigerina hispida are close to each other with values between $+2.46 \%$ $\pm 0.33 \%$ and $+2.72 \%$ $\pm 0.49 \%$, respectively. The $\delta^{18} \mathrm{O}$ of the intermediate infaunal Pullenia bulloides is $+2.01 \%$ o $\pm 0.19 \%$. The $\delta^{18} \mathrm{O}$ of the intermediate infaunal Bulimina inflata is $+1.56 \% \pm 0.08 \%$. The $\delta^{18} \mathrm{O}$ of Melonis barleeanus exhibit a remarkable variability with values ranging between $+0.52 \%$ and $+1.62 \%$ (Fig. 4 ).

\subsection{Benthic foraminiferal $\delta^{13} \mathrm{C}$ values at the Mahavavy slope station}


The $\delta^{13} \mathrm{C}$ values ranges between $-5.35 \% \neq \pm 0.29 \%$ and $-0.31 \% \pm \pm 1.49 \%$ (Fig. 4 ). The heavier $\delta^{13} \mathrm{C}$ signatures $(-0.31 \%$ o $\pm 1.49 \%$ and $-0.71 \%$ o $\pm 1.06 \%$ o $)$ are recorded by Hoeglundina elegans, which thrives in the first cm (Figs. $3 \mathrm{~b}$ and 4). H. elegans $\delta^{13} \mathrm{C}$ is depleted compared to bottom water $\delta^{13} \mathrm{C}_{\mathrm{DIC}}$. The $\delta^{13} \mathrm{C}$ of Bulimina marginata ranges between $-2.56 \%$ $\pm 0.93 \%$ and $-2.16 \%$ $\pm 0.88 \%$; this is much lower than $H$. elegans signature, and it shows minor changes with sediment depth. The $\delta^{13} \mathrm{C}$ of Bolivina alata (values comprised between $-3.55 \%_{0} \pm 0.29 \%$ and $-3.04 \%_{0} \pm 1.13 \%$ ) decreases slightly with sediment depth. The $\delta^{13} \mathrm{C}$ of Uvigerina hispida $(-2.56 \% \mathrm{*} \pm 1.04 \% \mathrm{n})$ is depleted compared to the $\delta^{13} \mathrm{C}$ of dissolved inorganic carbon in bottom water. The intermediate infaunal species, Bulimina inflata, Melonis barleeanus and Pullenia bulloides, present lower $\delta^{13} \mathrm{C}$ signatures ranging between $4.14 \%$ $\pm 1.26 \%$ and $-5.35 \%$ $\pm 0.29 \%$.

\section{Discussion}

\subsection{General remarks about intraspecific variability}

The metabolic-rate-dependant fractionation (and the preferential incorporation of isotopically-depleted metabolic $\mathrm{CO}_{2}$ when growth rate is enhanced) may induce an important intraspecific variability (so-called "ontogenetic" and "dimorphism" effects) of isotope signals (e.g., Schmield et al. 2004; Staines-Urías and Douglas, 2009; Filipsson et al., 2010; Schumacher et al., 2010; Theodor et al., 2016). Schumacher et al. (2010) documented that Uvigerina ex. gr. U. semiornata, which was sampled from the Pakistan continental margin, presents a $\delta^{13} \mathrm{C}$ increase of about $0.105 \%$ or for each $100-\mu \mathrm{m}$ increment in test size, whereas $\delta^{18} \mathrm{O}$ increases by 0.02 to $0.06 \%$ per $100 \mu \mathrm{m}$ increment. Schmiedl et al. (2004), who worked on living foraminifera from the Western Mediterranean Sea, described also a $0.8 \%$ o to $1.2 \%$ 
increase in the $\delta^{13} \mathrm{C}$ of Uvigerina mediterranea and a $0.3 \%$ to $0.4 \%$ increase in $\delta^{18} \mathrm{O}$ for a test size increase from 175 to $1250 \mu \mathrm{m}$. Theodor et al. (2016) noticed increasing stable isotope values with increasing test size in bi- or triserial taxa (genera Uvigerina and Globobulimina genera). We observe no systematical depletion of $\delta^{13} \mathrm{C}$ and $\delta^{18} \mathrm{O}$ in preadult individuals of Bulimina marginata, Bolivina alata and Uvigerina hispida compared to adult ones In the Mozambique Channel off Madagascar (Table 3). On the contrary, small-sized individuals present in most cases much heavier isotopes signals compared to larger ones (see, for instance, the $\delta^{18} \mathrm{O}$ of Bulimina marginata in cores MTB-7A, the $\delta^{13} \mathrm{C}$ of Bulimina marginata in cores MTB-7A; Table 3). We have fairly no explanation for such a pattern, but it is evident that our study gives the opportunity to focus on samples with few individuals (Table 3). For 70 samples, we have run analysis on a single specimen $(>9 \mu \mathrm{g})$, what results - for some species - in a tremendous intraspecific $\delta^{18} \mathrm{O}$ and $\delta^{13} \mathrm{C}$ variability. For example, the $\delta^{18} \mathrm{O}$ of Uvigerina hispida at the Betsiboka slope station has a mean value of 3.65\% in MTB-1A and MTB-1B duplicate cores with a standard deviation of $1.44 \%$, values ranging between $1.82 \%$ o and 5.27\% (Fig. 4; Table 3). Regarding the moderate $\delta^{18} \mathrm{O}$ variability generated by size effect (Schmield et al. 2004; Schumacher et al., 2010; Theodor et al., 2016), it is quite unreliable to justify the high intraspecific difference recorded in $U$. hispida only by the ontogenetic variable. Alternatively, intraspecific variability could be related to a random mixing between megalospheric and microspheric tests with different isotopes signatures. For instance, Uvigerina hispida presents a remarkable dimorphism between individuals with an acuminate/pointed end (microspheric/sexual generation) and specimens presenting a large and rounded end (megalospheric/asexual generation). Staínes-Urias and Douglas (2009) documented both generation types of Bolivina subadvena and Bolivina argentea in the Southern Gulf of Mexico. They recorded a relatively moderate $\delta^{13} \mathrm{C}$ differences (e.g., $\sim 0.9 \%$ ) and a minor $\delta^{18} \mathrm{O}$ variability between both generation morphotypes, with lighter values 
recorded in megalospheric tests. It is unlikely that only a dimorphism effect creates the large variability recorded in the $\delta^{18} \mathrm{O}$ of $U$. hispida and B. marginata. Furthermore, and as discussed by Ishimura et al. (2012), intraspecific variability could be related to the carbonate ion concentration $\left[\mathrm{CO}_{3}{ }^{2-}\right]$ in pore water, which varies within the sediment and throughout the time in function of decomposition of organic matter. Alternatively, the heterogeneity of intracellular $\mathrm{pH}$ when foraminifera calcify (as depicted by de Nooijer et al., 2009) might explain inter-individual isotopic variability.

Finally, in order to better assess the intraspecific variability recorded at our stations, it would have been relevant to complete our present study with a specific and thorough analysis of stable isotopes in function of (1) fine size subclasses and (2) perfectly discriminated generation types. Furthermore, it would be essential to get new environmental data concerning intra-annual variability of geochemical and physical conditions (e.g., pore-water $\delta^{18} \mathrm{O}$ and $\delta^{13} \mathrm{C}_{\mathrm{DIC}}$, temperature, alkalinity) prevailing at and below the sediment-water interface.

\subsection{Interspecific $\delta^{18} \mathrm{O}$ variability related to microhabitat}

As explained in Fontanier et al. (2016), living foraminifera investigated in this study occupy different microhabitats within sediments (Fig. 3). Hoeglundina elegans is considered a very shallow infaunal (VSI) taxon, which thrives very close to the sediment-water interface (SWI). As shallow infaunal (SI) species, Uvigerina hispida and Bulimina marginata occupy the first cm below the SWI (Fig. 3a-b). They rely on organic matter, which accumulate preferentially below the SWI (Fontanier et al., 2016). Bolivina alata, Pullenia bulloides, Bulimina inflata and Melonis barleeanus, which appear in sub-surface sediments, are considered intermediate infaunal (II) taxa capable to feed on altered organic matter under low- 
oxygen conditions (Fontanier et al., 2016) (Fig. 3a-b). Globobulimina barbata is a deep infaunal (DI) species, which lives around the oxygen penetration depth (OPD) several cm below the SWI. Considered facultative anaerobe, it is assumedly able to use nitrate to degrade altered organic compounds (Fontanier et al., 2016). The $\delta^{18} \mathrm{O}$ of these taxa changes systematically in relation to sediment depth (Figs 4 and 5). Schmiedl et al. (2004) and Theodor et al. (2016) described $\delta^{18} \mathrm{O}$ offsets between species directly related to preferential microhabitat; with higher values recorded for deep infaunal species and increasingly lighter values for intermediate to shallow infaunal taxon. However, Bolivina alata presents the heaviest signal recorded at the Betsiboka slope station, although this species occupy an intermediate infaunal microhabitat (Figs. 4 and 5). As previously indicated in Fontanier et al. (2006; 2008), our data suggests that the pattern of increasing $\delta^{18} \mathrm{O}$ with microhabitat depth cannot be systematically retained.

\subsection{Interspecific $\delta^{13} \mathrm{C}$ variability related to microhabitat}

Pore water $\delta^{13} \mathrm{C}_{\mathrm{DIC}}$ decreases from a value close to bottom water $\delta^{13} \mathrm{C}_{\mathrm{DIC}}$ at the sediment-water interface to much lighter values in deeper sediments. This is mainly a result of progressive mineralisation of organic matter buried in deeper sediments and the related release of ${ }^{12} \mathrm{C}$ by bacterial degradation (e.g., Grossman, 1984a, 1987; McCorkle et al, 1985, 1990; McCorkle and Emerson, 1988). Consequently, the higher the organic matter exportation at the seafloor is, the stronger the depletion of pore water $\delta^{13} \mathrm{C}_{\text {DIC }}$ will be (e.g., McCorkle and Emerson, 1988; McCorkle et al., 1990; Holsten et al., 2004; Schmiedl and Mackensen, 2006). In our study, low $\delta^{13} \mathrm{C}$ values of species thriving deeper in sediments confirm that infaunal benthic foraminifera record the $\delta^{13} \mathrm{C}_{\mathrm{DIC}}$ of pore water (Figs. 4 and 5) (e.g., McCorkle et al., 1990, 1997; Rathburn et al., 1996; Mackensen and Licari, 2004; Schmiedl et al., 2004; Holstein et al., 2004; Fontanier et al., 2006, 2008; Basak et al., 2009). The so-called 
microhabitat effect refers to carbonate precipitation in isotopically distinct growth environments. Because Hoeglundina elegans lives very close to the sediment-water interface (Fig. 3a-b), its $\delta^{13} \mathrm{C}$ values are close to bottom water $\delta^{13} \mathrm{C}_{\mathrm{DIC}}$ (Fig. 4 and 5). Bulimina marginata and Uvigerina hispida, which occupy the first $\mathrm{cm}$ below the SWI, exhibit depleted signals compared to H. elegans (Fig. 5). Pullenia bulloides, Bulimina inflata, Bolivina alata, Melonis barleeanus and Globobulimina barbata, which live in intermediate-to-deep infaunal microhabitats, have systematically lighter $\delta^{13} \mathrm{C}$ signatures, especially G. barbata and $M$. barleeanus thriving more or less close to OPD (e.g., McCorkle et al., 1990, 1997; Schmiedl et al., 2004; Fontanier et al., 2006, 2008; Theodor et al., 2016).

\subsection{Interspecific $\delta^{13} C$ variability related to sedimentary organic matter}

A precise comparison of interspecific $\Delta \delta^{13} \mathrm{C}$ values between both studied stations brings interesting insight and understanding on the role of organic matter exported at the seafloor on foraminiferal $\delta^{13} \mathrm{C}$ (Fig. 5). Whereas the Betsiboka slope station is characterized by relatively moderate content in sedimentary organic matter, the Mahavavy slope station presents higher organic matter content, especially in uppermost sediments where peculiar sedimentary facies, likely related to rare but extreme flood events, are enriched in organic carbon $(>2.0 \%$ DW) (Table 1) (Fontanier et al., 2016; submitted). When we compare interspecific $\delta^{13} \mathrm{C}$ variability between both stations, it appears that the $\Delta \delta^{13} \mathrm{C}$ between (very) shallow and intermediate infaunal taxa increases obviously with sedimentary organic matter enrichment and enhanced organic mineralization (as suggested by shallower OPD at the Mahavavy slope station). For instance, the $\Delta \delta^{13} \mathrm{C}$ between $H$. elegans and M. barleeanus is $2.78 \%$ at the Betsiboka slope station, and increases to $3.96 \%$ at the Mahavavy slope station. Accordingly, the $\Delta \delta^{13} \mathrm{C}$ between $U$. hispida and M. barleeanus is $1.18 \%$ at the Betsiboka slope station, whereas it increases to $1.96 \%$ at the Mahavavy slope station (Fig. 5). Same 
observations can be provided when we consider the $\Delta \delta^{13} \mathrm{C}$ between $B$. marginata and $M$. barleeanus. We propose in Figure 6 a synthetic scheme, which illustrates the effect of exported organic matter $(\mathrm{OM})$ on (1) bottom- and pore-water $\delta^{13} \mathrm{C}_{\mathrm{DIC}}$ and (2) foraminiferal

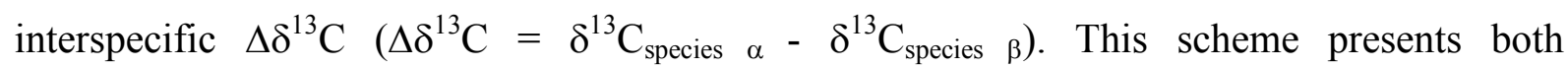
environmental settings described in this study. The setting (A) corresponds to a relatively moderate exportation of organic matter as documented at the Betsiboka slope station (Fontanier et al., 2016). The setting (B) corresponds to a high exportation of organic matter recorded at the Mahavavy slope station, where a strong source-to-sink connection between land and sea is assumed (Fontanier et al., 2016; submitted). In both environmental contexts, the profile of pore-water $\delta^{13} \mathrm{C}_{\mathrm{DIC}}$ is dependent on $\mathrm{OM}$ mineralization below the SWI (e.g., McCorkle and Emerson, 1988; McCorkle et al., 1990; Holsten et al., 2004; Schmiedl and Mackensen, 2006). Consequently, pore-water $\delta^{13} \mathrm{C}_{\text {DIC }}$ profile exhibits a stronger depletion with sediment depth in the scenario B compared to the scenario A. In both settings, bottom water, which is well-oxygenated $(>180 \mu \mathrm{mol} / \mathrm{L})$, does not play a discriminating role on insediment biogeochemical process (Fontanier et al., 2016). That being said, as far as oxygen penetration depth in the sediment (OPD) is controlled by organic matter decomposition below sediment-water interface (SWI), oxygen penetration depth (OPD) is shallower in setting $\mathrm{B}$ compared to setting A. In agreement with our data, we discriminate $\delta^{13} \mathrm{C}$ of living foraminifera occupying very shallow infaunal $\left(\delta^{13} \mathrm{C}_{\mathrm{VSI}}\right)$, shallow infaunal $\left(\delta^{13} \mathrm{C}_{\mathrm{SI}}\right)$, intermediate infaunal $\left(\delta^{13} \mathrm{C}_{\mathrm{II}}\right)$ and deep infaunal $\left(\delta^{13} \mathrm{C}_{\mathrm{DI}}\right)$ microhabitat. According to our model, foraminiferal $\delta^{13} \mathrm{C}$ follows fairly well the profile of pore-water $\delta^{13} \mathrm{C}_{\text {DIC. }}$ Therefore, interspecific $\Delta \delta^{13} \mathrm{C}$ between living foraminifera presenting different microhabitat is generally higher in setting B, when organic matter mineralization and exportation are enhanced. Finally, as already discussed in previous works (e.g., McCorkle and Emerson, 1988; Schmiedl et al., 2004; Fontanier et al., 2006; Schmiedl and Mackensen, 2006, Theodor et al, 2016), the $\Delta \delta^{13} \mathrm{C}$ 
between species with different microhabitats can be considered a reliable proxy of exported organic matter flux.

\section{Conclusions}

Oxygen and carbon isotopes $\left(\delta^{18} \mathrm{O}\right.$ and $\left.\delta^{13} \mathrm{C}\right)$ have been investigated in carbonate tests of 8 deep-sea foraminiferal taxa living in the Mozambique Channel (eastern Africa) to understand how environmental constraints (e.g., organic matter, oxygenation) control intraand interspecific variability of isotope signatures.

- The $\delta^{18} \mathrm{O}$ values of foraminiferal taxa are obviously not controlled by microhabitat pattern. Some species (Bulimina marginata, Uvigerina hispida) present a tremendous but unexplained intraspecific variability, which does not follow the classical ontogenetic effect (when tested).

- The $\delta^{13} \mathrm{C}$ values of foraminiferal taxa do neither record bottom water $\delta^{13} \mathrm{C}$ DIC in a 1:1 relationship nor with a constant offset, but are mainly controlled by microhabitat effects. The decrease of $\delta^{13} \mathrm{C}$ values of (very) shallow, intermediate and deep infaunal taxa at the deeper station compared to the shallower one reflects the enhanced mineralization of sedimentary organic matter below the sediment-water interface.

- The $\Delta \delta^{13} \mathrm{C}$ between shallow to very-shallow infaunal species (i.e., Hoeglundina elegans, Uvigerina hispida) and intermediate/deep infaunal species (i.e., Melonis barleeanus, Globobulimina barbata) can shed light on the exportation of organic matter at the seafloor off North-Western Madagascar. 


\section{Acknowledgements}

This study was done in the framework of the PAMELA project ("Passive Margin Exploration Laboratories") funded by TOTAL and Ifremer. We thank crew members of the $\mathrm{R} / \mathrm{V}$ L'Atalante and all scientists who participated to the PAMELA-MOZ1 cruise. We sincerely acknowledge Karine Olu (Ifremer) and Stephan Jorry (Ifremer) for their very efficient work as chief scientist, in the organisation and the progress of the cruise. We have special thoughts for Lara Macheriotou ( $\mathrm{PhD}$, Ghent University) who sampled cores dedicated to foraminiferal investigation. We thank Heather Birch for her help to get $\delta^{13} \mathrm{C}_{\text {DIC }}$ values extracted from the World Ocean Database 2009 (WOD09 files in http://www.nodc.noaa.gov/OC5/WOD/pr_wod.html). The Eline Garnier's fellowship was funded by the ECOBIOC team from the laboratory "Environnements et Paléo-environnements Océaniques et Continentaux" (UMR 5805), University of Bordeaux. Finally, we thank both reviewers for their comments, which were helpful to improve the overall quality of this paper.

\section{References}

Antoine, D., André, J.-M., and Morel, A., 1996, Oceanic primary production 2. Estimation at global scale from satellite (coastal zone color scanner) chlorophyll: Global Biogeochemical Cycles, v. 10, p. 57-69.

Barnett, P.R.O., Watson, J., and Connely, D., 1984, A multiple corer for taking virtually undisturbed sample from shelf, bathyal and abyssal sediments: Oceanologica Acta, v. 7, p. 399-408.

Basak, C., Rathburn, A.E., Pérez, M.E., Martin, J.B., Kluesner, J.W., Levin, L.A., De Deckker, P., Gieskes, J.M., and Abriani, M., 2009, Carbon and oxygen isotope 
geochemistry of live (stained) benthic foraminifera from the Aleutian Margin and the Southern Australian Margin: Marine Micropaleontology, v. 70, p. 89-101.

Berthois, L., and Crosnier, A., 1965, La sédimentation dans l'estuaire de la Betsiboka (côte Ouest de Madagascar) et sur le plateau continental au large de l'estuaire: Sédimentologie. Comptes Rendus de l'Académie de Sciences Paris, v. 261, p. 3647-3649.

Corliss, B.H., McCorkle, D.C., and Higdon, D.M., 2002, Seasonal changes of the carbon isotopic composition of deep-sea benthic foraminifera: Paleoceanography, v. 17, doi:10.1029/2001PA000664.

Corliss, B.H., Sun, X., Brown, C.W., and Showers, W.J., 2006, Influence of seasonal primary productivity on d13C of North Atlantic deep-sea benthic foraminifera: Deep-Sea Research Part-I, v. 53, p. 740-746.

de Nooijer, L. J., Toyofuku, T., Kitazato, H., 2009, Foarminifera promote calcification by elevating their intracellular $\mathrm{pH}$, Proceedings of the National Academy of Sciences of the United States of America, 106, 15374-15378.

Dunbar, R.B., and Wefer, G., 1984, Stable isotope fractionation in benthic foraminifera from the Peruvian continental margin: Marine Geology, v. 59, p. 215-25.

Eberwein, A., and Mackensen, A., 2006, Regional primary productivity differences off Morocco (NW-Africa) recorded by modern benthic foraminifera and their stable carbon isotopic composition: Deep-Sea Research Part I, v. 53, p. 1379-1405.

Filipsson, H.L., Nordberg, K., and Gustafsson, M., 2004, Seasonal study of $\delta^{18} \mathrm{O}$ and $\delta^{13} \mathrm{C}$ in living (stained) benthic foraminifera from two Swedish fjords: Marine Micropaleontology, v. 53, p. 159-172.

Filipsson, H. L., Bernhard, J. M., Lincoln, S. A., McCorkle, D. C., 2010, A culture-based calibration of benthic foraminiferal paleotemperature proxies: $\delta^{18} \mathrm{O}$ and $\mathrm{Mg} / \mathrm{Ca}$ results. Biogeosciences Discussions, v. 7, 351-385. 
Fontanier, C., Mackensen, A., Jorissen, F.J., Anschutz, P., Licari, L., and Griveaud, C., 2006, Stable oxygen and carbon isotopes of live benthic foraminifera from the Bay of Biscay: microhabitats impact and seasonal variability: Marine Micropaleontology, v. 58, p. 159183.

Fontanier, C., Jorissen, F.J., Michel, E., Cortijo, E., Vidal, L., and Anschutz, P., 2008, Stable oxygen and carbon isotopes of live (stained) benthic foraminifera from Cap-Ferret Canyon (Bay of Biscay): Journal of Foraminiferal Research, v. 38, p. 39-51.

Fontanier, C., Koho, K. A., Goñi-Urriza, M.S., Deflandre, B., Galaup, S., Ivanovsky, A., Gayet, N, Dennielou, B, Grémare, A., Bichon, S., Gassie, C., Anschutz, P., Duran, R., and Reichart, G. J., 2014, Benthic Foraminifera from the deep-water Niger delta (Gulf of Guinea): Assessing present-day and past activity of hydrate pockmarks: Deep-Sea Research part-I, v. 94, p. 87-106.

Fontanier, C., Garnier, E., Brandily, C., Dennielou, B., Bichon, S., Gayet, N., Eugène, T., Rovere, M., Grémare, A., Deflandre, B., 2016, Living (stained) benthic foraminifera from the Mozambique Channel (eastern Africa): Exploring ecology of deep-sea unicellular meiofauna: Deep-Sea part-1, http://dx.doi.org/10.1016/j.dsr.2016.06.007

Fontanier, C., Toucanne, S., Bayon, G., Schmidt, S., Deflandre, B., Dennielou, B., Jouet, G., Garnier, E., Sakai, S., Martinez Lamas, R., Duros, P., Toyofuku, T., Salé, A., Belleney, D., Bichon, S., Boissier A., Chéron, S., Pitel, M., Roubi, A., Rovere, M., Grémare, A., Jorry, S. J., Deep-sea ecosystems are threatened by deforestation in Madagascar. Submitted in Nature Ecology and Evolution

Grossman, E.L., 1984a, Carbon isotopic fractionation in live benthic foraminifera comparison with inorganic precipitate studies: Geochemica et Cosmochimica Acta, v. 48, p. $1505-1512$. 
Grossman, E.L, 1984b, Stable isotope fractionation in live benthic foraminifera from the southern California borderland: Palaeoceanography, Palaeoclimatology, Palaeoecology, v. 47, p. $301-327$.

Grossman, E.L., 1987, Stable isotopes in modern benthic foraminifera: a study of vital effect. Journal of Foraminiferal Research, v. 17, p. 48-61.

Hill, T.M., Kennett, J.P., and Valentine, D.L., 2004, Isotopic evidence for the incorporation of methane-derived carbon into foraminifera from modern methane seeps, Hydrate Ridge, Northeast Pacific: Geochimica et Cosmochimica Acta, v. 68, p. 4419-4627.

Holsten, J., Stott, L., Berelson, W., 2004, Reconstructing benthic carbon oxidation rates using $\delta^{13} \mathrm{C}$ of benthic foraminifers: Marine Micropaleontology, v. 53, p. 117-132.

Ishimura, T., Tsunogai, U., Hasegawa, S., Nakagawa, F., Oi, T., Kitazato, H., Suga, H., and Toyofuku, T., 2012, Variation in stable carbon and oxygen isotopes of individual benthic foraminifera: tracers for quantifying the magnitude of isotopic disequilibrium, Biogeosciences, v. 9, p. 4353-4367.

Jorry, S. J., 2014, PTOLEMEE cruise, R.V. L'Atalante, http://dx.doi.org/10.17600/14000900

Kroopnick, P., 1985, The distribution of $\delta^{13} \mathrm{C}$ of $\Sigma \mathrm{CO} 2$ in the world oceans: Deep-Sea Research, v. 32, p. 57-84.

Lebigre, J.M., 1990, Les marais maritimes de Gabon et de Madagascar. Contribution à l'étude d'un milieu tropical : PhD thesis, Institut de Géographie, Université de Bordeaux III, 988 pp.

Machu, E., and Garçon, V., 2001, Phytoplankton seasonal distribution from SeaWIFS data in the Agulhas Current system: Journal of Marine Research, v. 59, p. 795-812.

Mackensen, A., 2008, On the use of benthic foraminiferal $\delta^{13} \mathrm{C}$ in paleoceanography: constraints from primary proxy relationships. In: Austin, W. E. N., James, R. H. (Eds), 
Biogeochemical controls on Palaeoceanographic Environmental Proxies. Geological Society, London, Special publications, v. 303, pp. 121-133.

Mackensen, A., 2013, High epibenthic foraminiferal $\delta^{13} \mathrm{C}$ in the Recent deep Arctic Ocean: implications for ventilation and brine release during stadials: Paleoceanography, v.28, p. $574-584$.

Mackensen, A., and Douglas, R.G., 1989, Down-core distribution of live and dead benthic foraminifera in box cores from the Weddell Sea and the California continental borderland: Deep-Sea Research, v. 36, p. 879-900.

Mackensen, A., and Licari, L., 2004, Carbon isotopes of live benthic foraminifera from the South Atlantic Ocean: Sensitivity to bottom water carbonate saturation state and organic matter rain rates, In: Wefer, G., Mulitza, S., Rathmeyer, V. (Eds.), The South Atlantic in the Late Quaternary - Reconstruction of Material Budget and Current Systems, SpringerVerlag, Berlin, pp. 623-644.

Mackensen, A., Hubberten, H.-W., Bickert, T., Fischer, G., and Futterer, D.K., 1993, $\delta^{13}$ C in benthic foraminiferal tests of Fontbotia wuellerstorfi (Schwager) relative to $\delta^{13} \mathrm{C}$ of dissolved inorganic carbon in Southern Ocean deep water: implications for Glacial ocean circulation models: Paleoceanography, v. 6, p. 587-610.

Mackensen, A., Schumacher, S., Radke, J., and Schmidt, D.N., 2000, Microhabitat preferences and stable carbon isotopes of endobenthic foraminifera: clue to quantitative reconstruction of oceanic new production: Marine Micropaleontology, v. 40, p. 233-258.

Mackensen, A., Wollenburg, J., and Licari, L., 2006, Low $\delta^{13} \mathrm{C}$ in tests of live epibenthic and endobenthic foraminifera at a site of active methane seepage: Paleoceanography, v. 21, doi:10.1029/2005PA001196. 
Martin, R. A., Nesbitt, E. A., Campbell, K. A., 2010, The effects of anaerobic methane oxidation on benthic foraminiferal assemblages and stable isotopes on the Hikurangi Margin of eastern New Zealand: Marine Geology, v. 272, p. 270-284.

McCorkle, D.C., Emerson, S.R., and Quay, P., 1985, Stable carbon isotope in marine porewaters: Earth and Planetary Science Letters, v. 74, p. 13-26.

McCorkle, D.C., and Keigwin, L.D., 1994, Depth profile of $\delta^{13} \mathrm{C}$ in bottom water and coretop C. wuellerstorfi on the Ontong-Java Plateau and Emperor Seamounts. Paleoceanography, v. 9, p. 197-208.

McCorkle, D.C., Keigwin, L.D., Corliss, B.H., and Emerson, S.R., 1990, The influence of microhabitats on the carbon isotopic composition of deep-sea benthic foraminifera: Paleoceanography, v. 5, p. 161-185.

McCorkle, D.C., Corliss, B.H., and Farnham, C.A., 1997, Vertical distributions and stable isotopic compositions of live (stained) benthic foraminifera from the North Carolina and California continental margin: Deep-sea Research part-I, v. 44, p. 983-1024

Murray, J. W., and Bowser, S. S., 2000, Mortality, protoplasm decay rate, and reliability of staining techniques to recognize "living" foraminifera: a review: Journal of Foraminiferal Research, v. 30, p. 66-70.

Olu, K.,2014, PAMELA-MOZ01 cruise, RV L'Atalante, http://dx.doi.org/10.17600/14001000

Panieri, G., 2006, Foraminiferal response to an active methane seep environment: A case study from the Adriatic Sea: Marine Micropaleontology, v. 61, p. 116-130.

Raj, R. P., Peter, B. N., and Pushpadas, D., 2010, Oceanic and atmospheric influences on the variability of phytoplankton bloom in the Southwestern Indian Ocean: Journal of Marine Systems, v. 82, p. 217-229. 
Ralison, O. H., Borges, A. V., Dehairs, F., Middelburg, J. J., and S. Bouillon, 2008, Carbon biogeochemistry of the Betsiboka estuary (north-western Madagascar): Organic Geochemistry, doi:10.1016/j.orggeocem.2008.01.010.

Rathburn, A.E., Corliss, B.H., Tappa, K.D., and Lohmann, K.C., 1996, Comparison of the ecology and stable isotopic compositions of living (stained) benthic foraminifera from the Sulu and South China Seas: Deep-Sea Research, v. 43, p. 1617-1646.

Rathburn, A.E., Levin, L.A., Held, Z., and Lohmann, K.C., 2000, Benthic foraminifera associated with cold methane seeps on the northern California margin: Ecology and stable isotopic composition: Marine Micropaleontology, v. 38, p. 247-266.

Rathburn, A.E., Pérez, M.E., Martin, J.B., Day, S.A., Mahn, C., Gieskes, J., Ziebis, W., Williams, D., and Bahls, A., 2003, Relationships between the distribution and stable isotopic composition of living benthic foraminifera and cold methane seep biogeochemistry in Monterey Bay, California: Geochemistry, Geophysics, Geosystems, v. 4, p. 1-28.

Ridderinkhof, H., and de Ruijter, W.P.M., 2003, Moored current observations in the Mozambique Channel: Deep-Sea Research part II, v. 50, p. 1953-1955.

Ridderinkhof, H., van der Werf, P.M., Ullgren, J.E., van Aken, H.M., van Leeuwen, P.J., and de Ruijter, W.P.M., 2010, Seasonal and interannual variability in the Mozambique Channel from moored current observations: Journal of Geophysical Research, v. 115, http://dx.doi.org/10.1029/2009JC005619.

Roman, R.E., and Lutjeharms, J.R.E., 2009, Red Sea Intermediate Water in the source regions of the Agulhas Current: Deep-Sea Research part-I, v. 56, p. 939-962.

Schmiedl, G., Pfeilsticker, M., Hemleben, C., and Mackensen, A., 2004, Environmental and biological effects on the stable isotope composition of Recent deep-sea benthic foraminifera from the Mediterranean Sea: Marine micropaleontology, v. 51, p. 129-152. 
Schmiedl, G., Mackensen, A., 2006. Multispecies stable isotopes of benthic foraminifers reveal past changes of organic matter decomposition and deepwater oxygenation in the Arabian Sea: Paleoceanography, v. 21, doi:10.1029/2006PA001284.

Schouten, M.W., de Ruijter, W.P.M., van Leeuwen, P.J., and Ridderinkhof, H., 2003, Eddies and variability in the Mozambique Channel: Deep-Sea Research part II, v. 50, p. $1987-$ 2003.

Schumacher, S., Jorissen, F.J., Mackensen, A., Gooday, A.J., and Pays, O., 2010, Ontogenetic effects on stable carbon and oxygen isotopes in tests of live (Rose Bengal stained) benthic foraminfiera from the Pakistan continental margin: Marine Micropaleontology, v. 76, p. $92-103$.

Sen Gupta, B.K., and Aharon, P., 1994, Benthic foraminifera of bathyal hydrocarbon vents of the Gulf of Mexico: Initial Report on communities and stable isotopes: Geo-Marine Letters, v. 14, p. 88-96.

Sen Gupta, B.K., Platon, E., Bernhard, J.M., and Aharon, P., 1997, Foraminiferal colonization of hydrocarbon-seep Bacterial mats and underlying sediment, Gulf of Mexico slope: Journal of Foraminiferal Research, v. 27, p. 292-300.

Staines-Urías, F., and Douglas, R.G., 2009, Environmental and intraspecific dimorphism effects on the stable isotope composition of deep-sea benthic foraminifera from the Southern Gulf of California, Mexico: Marine Micropaleontology, v. 71, p. 80-95.

Ternon, J.F., Roberts, M.J., Torris, T., Hancke, L., and Backeberg, B., 2014, In situ measured current structures of the eddy field in the Mozambique Channel: Deep-Sea Research part II, v. 100, p. 10-26.

Tew-Kai, E., and Marsac, F., 2009, Patterns of variability of sea surface chlorophyll in the Mozambique Channel: a quantitative approach: Journal of Marine Systems, v. 77, p. 7788. 
Theodor, M., Schmiedl, G., Mackensen, A., 2016. Stable isotope composition of deep-sea benthic foraminifera under contrasting trophic conditions in the western Mediterranean Sea, v. 124, p. 16-28.

Torres, M.E., Mix, A.C., Kinports, K., Haley, B., Klinkhammer, G.P., McManus, J., and de Angelis, M.A., 2003, Is methane venting at the seafloor recorded by $\delta^{13} \mathrm{C}$ of benthic foraminifera shells?: Paleoceanography, v. 18, doi:10.1029/2002PA000824.

Ullgren, J.E., van Aken H.M., Ridderinkhof, H., and de Ruijter, W.P.M., 2012, The hydrography of Mozambique Channel from six years of continuous temperature, salinity, and velocity observations: Deep-Sea Research part I, v. 69, p. 36-50.

Walton, W. R., 1952, Techniques for recognition of living Foraminifera: Contributions from the Cushman Foundation for Foraminiferal Research, v 3, p. 56-60.

Woodruff, F., Savin, S.M., Douglas, R.G., 1980, Biological fractionation of oxygen and carbon isotopes by recent benthic foraminifera: Marine Micropaleontology, v. 5, p. 3-11. Zeebe, R.E., Wolf-Gladrow, D.W., 2001, $\mathrm{CO}_{2}$ in seawater: equilibrium, kinetics, isotopes: Elsevier Oceanography Book Series, v. 65. 346 pp.

\section{Table Captions}

Table 1. Location and physiographical description of the 2 stations sampled during the PAMELA-MOZ1 cruise (October 2014). Two multi-corer deployments were operated at each site. Coordinates and depth of all deployments are described. Physico-chemical parameters including BWT (bottom-water temperature) and BWS (bottom-water salinity) were extrapolated from CTD casts achieved during the ACSEX cruise (single asterisk) (data available at http://www.nioz.nl/codis). $\mathrm{BWO}_{\text {meas }}$ (measured bottom-water oxygen) was measured in water overlying the sediment-water interface (SWI) of cores gathered at the 
occasion of the PAMELA-MOZ1 cruise. Oxygen saturation and $\mathrm{BWO}_{\text {sat }}$ (bottom-water oxygen at saturation) were calculated on http://ocean.ices.dk/Tools/Calculator.aspx. AOU (Apparent Oxygen Utilisation) and the $\delta^{13} \mathrm{C}$ of dissolved inorganic carbon in bottom water $\left(\delta^{13} \mathrm{C}_{\mathrm{DIC}}\right)$ were calculated using the Kroopnick's equation (Kroopnick, 1985) (see Materialand-Methods section). The $\delta^{13} \mathrm{C}_{\text {DIC }}$ values with double asterisks were extracted from the World Ocean $\quad$ Database 2009 (WOD09 files http://www.nodc.noaa.gov/OC5/WOD/pr_wod.html). We used a $\delta^{13} \mathrm{C}_{\text {DIC }}$ vertical profile in the water column, which was performed at a station located in the Comoro Basin in January 1996 (station ID: 4175, Latitude $-11^{\circ} 42.0^{\prime} \mathrm{N}$; Longitude $48^{\circ} 34.9^{\prime} \mathrm{E}$ ). OPD (oxygen penetration depth) was determined by microprofiles in sediment cores (Fontanier et al., 2016).

Table 2. Geochemical and sedimentological features of the two investigated stations. Only means values are presented (for more details about methods and abbreviations, see Fontanier et al, 2016). Total organic carbon (TOC), $\mathrm{C} / \mathrm{N}$ atomic ratios (i.e. TOC/TN), stable carbon isotopes of organic matter $\left(\delta^{13} \mathrm{C}_{\mathrm{OM}}\right)$, Total hydrolysable amino acids (THAA), enzymatically hydrolysable amino acids (EHAA), EHAA/THAA percentage ratios (lability of amino acids), content in chlorophyllic pigment (i.e. $\mathrm{Chl}$ a and $\mathrm{Pheo} a)$ and $[\mathrm{Chl} \mathrm{a/(Chl} \mathrm{a+Pheo} \mathrm{a)]} \mathrm{ratios}$ (i.e.,freshness index) $\quad \mathrm{D}_{10}, \mathrm{D}_{50}$, and $\mathrm{D}_{90}$ represent respectively the $10^{\text {th }}, 50^{\text {th }}$ and $90^{\text {th }}$ percentiles in terms of grain-size distribution.

Table 3. Isotope analyses for all foraminiferal taxa studied at both stations ( 2 duplicate cores per station). 8 species were investigated: Bolivina alata, Bulimina inflata, Bulimina marginata, Globobulimina barbata, Hoeglundina elegans, Melonis barleeanus, Pullenia bulloides, Uvigerina hispida. Numbers (No) of individuals used for measurements and related 
weights are presented. An asterisk indicates when measurement was exclusively run on smallsized (preadult) individuals belonging to the $>125-\mu \mathrm{m}$-size fraction.

\section{Figure Captions}

Figure 1. Bathymetry and location of the two investigated stations in the Mozambique Channel (eastern Africa). Bathymetry has been acquired during the PTOLEMEE cruise using a EM302 multibeam echosounder (Jorry, 2014). At each station, both multi-corer deployments are indicated. Stations, multi-corer depths and geographic positions are listed in Table 1. The black star corresponds to the station 4175 (Latitude $-11^{\circ} 42.0^{\prime} \mathrm{N}$; Longitude $48^{\circ} 34.9^{\prime} \mathrm{E}$ ) for which temperature, salinity, dissolved oxygen and $\delta^{13} \mathrm{C}_{\mathrm{DIC}}$ in the water column were produced in January 1996. Those values are available in World Ocean Database 2009 (WOD09 files in http://www.nodc.noaa.gov/OC5/WOD/pr_wod.html).

Figure 2. Temperature, salinity, dissolved oxygen and $\delta^{13} \mathrm{C}_{\text {DIC }}$ profiles in the water column at the station 4175 (Latitude $-11^{\circ} 42.0^{\prime} \mathrm{N}$; Longitude $48^{\circ} 34.9^{\prime} \mathrm{E}$ ). Those values are available in World Ocean $\quad$ Database 2009 (WOD09 files http://www.nodc.noaa.gov/OC5/WOD/pr_wod.html). Water mass structure and multi-corer deployment depth (MTB-1, MTB-2, MTB-6, MTB-7) are indicated. RSW: Red Sea Water; SICW: South Indian Central Water; AAIW: Antarctic Intermediate Water; NADW: North Atlantic Deep Water.

Figure 3a-b. Down core distribution of foraminiferal taxa in the 4 cores gathered at the 2 stations (2 duplicate cores per station). Only species, which are investigated for their stable 
isotopes, are pictured. The number of individuals belonging to the $>125-\mu \mathrm{m}$ fraction found in each level is standardized for a $50-\mathrm{cm}^{3}$ sediment volume. Oxygen penetration depth (OPD) is indicated by arrow. Data have already been presented and discussed in Fontanier et al. (2016).

Figure $4 \delta^{18} \mathrm{O}$ and $\delta^{13} \mathrm{C}$ isotopic signatures for the main foraminiferal taxa in relation to sediment depth. Mean values between replicate cores are calculated and pictured. Horizontal bars represent standard deviations calculated when several isotopic measurements for the same depth interval are available in a single or in both replicate cores. To make discrimination between interspecific data easier, we have shifted some measurement values. Each grey box regroups all measurements, which are related to the same sediment depth. Oxygen penetration depth in the sediment (OPD) is indicated. The dotted lines depict the bottom-water $\delta^{13} \mathrm{C}_{\mathrm{DIC}}$ (Table 1).

Figure $5 \delta^{18} \mathrm{O}$ and $\delta^{13} \mathrm{C}$ isotopic signatures for the main foraminiferal taxa in relation to microhabitat patterns. Intraspecific mean values are calculated per station (including data from replicate cores for all sediment intervals). Horizontal bars represent standard deviations. The numbers (n) of measurements used to calculate intraspecific mean values is indicated above graphic data. We discriminate very shallow infaunal (VSI), shallow infaunal (SI), intermediate infaunal (II) and deep infaunal (DI) microhabitat. The dotted lines depict the bottom-water $\delta^{13} \mathrm{C}_{\text {DIC }}$ (Table 1).

Figure 6 Synthetic scheme illustrating the effect of exported organic matter (OM) on (1) bottom- and pore-water $\delta^{13} \mathrm{C}_{\mathrm{DIC}}$ (violet dotted line) and (2) foraminiferal interspecific $\Delta \delta^{13} \mathrm{C}$ $\left(\Delta \delta^{13} \mathrm{C}=\delta^{13} \mathrm{C}_{\text {species } \alpha}-\delta^{13} \mathrm{C}_{\text {species } \beta}\right)$. The OM exportation at the sediment-water interface is pictured by green arrows. The sediment-water interface (SWI) is indicated by brown 
horizontal lines. The profile of pore-water $\delta^{13} \mathrm{C}_{\mathrm{DIC}}$ is assumedly dependant on OM degradation below the SWI (e.g., McCorkle and Emerson, 1988; McCorkle et al., 1990; Holsten et al., 2004; Schmiedl and Mackensen, 2006). The environmental setting (A) corresponds to a relatively moderate exportation of organic matter (thin green arrows) as documented at the Betsiboka slope station. The environmental setting (B) corresponds to a high exportation of organic matter (thick green arrows) as documented at the Mahavavy slope station. In both contexts, bottom water is well-oxygenated (>180 $\mu \mathrm{mol} / \mathrm{L})$ (Fontanier et al., 2016). Oxygen penetration depth in the sediment (OPD) is indicated by red hatched line. We discriminate $\delta^{13} \mathrm{C}$ of living foraminifera occupying very shallow infaunal $\left(\delta^{13} \mathrm{C}_{\mathrm{VSI}}\right)$, shallow infaunal $\left(\delta^{13} \mathrm{C}_{\mathrm{SI}}\right)$, intermediate infaunal $\left(\delta^{13} \mathrm{C}_{\mathrm{II}}\right)$ and deep infaunal $\left(\delta^{13} \mathrm{C}_{\mathrm{DI}}\right)$ microhabitat. According to our scheme, foraminiferal $\delta^{13} \mathrm{C}$ follows fairly well the profile of pore-water $\delta^{13} \mathrm{C}_{\mathrm{DIC}}$. Therefore, interspecific $\Delta \delta^{13} \mathrm{C}$ between living foraminifera presenting different microhabitat is generally higher in scenario $\mathrm{B}$, when organic matter mineralization and exportation are enhanced. 


\begin{tabular}{|c|c|c|c|c|c|c|c|c|c|c|c|c|c|c|}
\hline Sites & Physiography & $\begin{array}{c}\text { Multi-corer } \\
\text { Deployment(s) }\end{array}$ & $\begin{array}{l}\text { Latitude } \\
\text { (N) }\end{array}$ & $\begin{array}{l}\text { Longitude } \\
\text { (E) }\end{array}$ & $\begin{array}{c}\text { Depth } \\
\text { (m) }\end{array}$ & $\begin{array}{l}\text { BWT } \\
\left({ }^{\circ} \mathrm{C}\right)\end{array}$ & BWS & $\begin{array}{c}\text { BWO }_{\text {meas }} \\
(\mu \mathrm{mol} / \mathrm{L})\end{array}$ & $\begin{array}{c}\text { Oxygen } \\
\text { saturation } \\
(\%)\end{array}$ & $\begin{array}{r}\text { BWO }_{\text {sat }} \\
(\mu \mathrm{mol} / \mathrm{L})\end{array}$ & $\underset{(\mu \mathrm{mol} / \mathrm{L})}{\mathrm{AOU}}$ & $\begin{array}{c}\delta^{13} \mathrm{C}_{\text {IC }} \\
(\% \%)\end{array}$ & $\begin{array}{l}\delta^{13} \mathbf{C}_{\mathrm{DIC}} \\
(\%)^{* *}\end{array}$ & $\begin{array}{l}\text { OPD } \\
(\mathrm{mm})\end{array}$ \\
\hline "Betsiboka slope" & $\begin{array}{l}\text { Malagasy upper slope, off } \\
\text { Betsiboka river }\end{array}$ & $\begin{array}{l}\text { MTB-1 } \\
\text { MTB-2 }\end{array}$ & $\begin{array}{l}-15^{\circ} 22.047^{\prime} \\
-15^{\circ} 22.063^{\prime}\end{array}$ & $\begin{array}{l}45^{\circ} 59.210^{\prime} \\
45^{\circ} 59.212^{\prime}\end{array}$ & $\begin{array}{l}529 \\
527\end{array}$ & $10.6^{*}$ & $34.9^{*}$ & 190 & $68 \%$ & 279 & 89 & 0.9 & 1.1 & 30 \\
\hline "Mahavayy slope" & $\begin{array}{l}\text { Malagasy upper slope, off } \\
\text { Mahavavy river }\end{array}$ & $\begin{array}{l}\text { MTB-6 } \\
\text { MTB-7 }\end{array}$ & $\begin{array}{l}-15^{\circ} 31.148^{\prime} \\
-15^{\circ} 31.155^{\prime}\end{array}$ & $\begin{array}{l}45^{\circ} 42.931^{\prime} \\
45^{\circ} 42.943^{\prime}\end{array}$ & $\begin{array}{l}789 \\
776\end{array}$ & $7.5^{*}$ & $34.7^{*}$ & 178 & $60 \%$ & 299 & 121 & 0.6 & 0.7 & 15 \\
\hline
\end{tabular}




\begin{tabular}{|c|c|c|c|c|c|c|c|c|c|c|c|c|c|c|}
\hline \multirow[t]{3}{*}{ Sites } & \multirow[t]{3}{*}{ Depth (m) } & \multicolumn{9}{|c|}{ Geochemical features } & \multicolumn{4}{|c|}{ Sedimentological features } \\
\hline & & TOC & $\mathrm{C} / \mathrm{N}$ & $\delta^{13} \mathrm{COM}_{\mathrm{OM}}$ & THAA & EHAA & EHAA/THAA & $\mathrm{Chl} a$ & $\begin{array}{r}{[\mathrm{Chl} a /(\mathrm{Ch} l} \\
a+\operatorname{Phe} a)]\end{array}$ & $\mathrm{CaCO}_{3}$ & $D_{10}$ & $\mathrm{D}_{50}$ & $\mathrm{D}_{90}$ & Lithology \\
\hline & & $(\% \mathrm{DW})$ & Atomic Ratio & $(\%)$ & (mg/g DW) & $(\mathrm{mg} / \mathrm{g} \mathrm{DW})$ & (\%) & $(\mu \mathrm{g} / \mathrm{g} \mathrm{FW})$ & (\%) & $(\% \mathrm{DW})$ & $(\mu \mathrm{m})$ & $(\mu \mathrm{m})$ & $(\mu \mathrm{m})$ & \\
\hline iboka slope" & $\sim 529$ & $1.2 \pm 0.1$ & $9.4 \pm 0.2$ & -20.49 & $4.45 \pm 0.45$ & $0.41 \pm 0.12$ & $9.1 \pm 2.0$ & $.27 \pm 0.13$ & $9.3 \pm 1.8$ & $31.7 \pm 1.9$ & $2 \pm 0$ & $10 \pm 1$ & $51 \pm 5$ & Silty Clay \\
\hline & $\sim 789$ & $1.6 \pm 0.4$ & $9.7 \pm 0.5$ & -21.87 & $5.80 \pm 1.32$ & $0.70 \pm 0.23$ & $12.0 \pm 2.9$ & $0.39 \pm 0.22$ & $7.4 \pm 1.6$ & $11.0 \pm 10.7$ & $2 \pm 0$ & $10 \pm 1$ & $41 \pm 4$ & Silty Clay \\
\hline
\end{tabular}


Table 3 (A)

\begin{tabular}{|c|c|c|c|c|c|c|c|}
\hline Measurement No & Core & Species Name & Sediment interval & Individual No & Weight (ug) & $\delta^{13} \mathrm{C}$ (\%。 VPDB) & $\delta^{18} \mathrm{O}(\% \mathrm{VPDB})$ \\
\hline $16020329-1$ & MTB-01A & Bulimina marginata* & $0-0.5 \mathrm{~cm}$ & 2 & 13 & -0.03 & 3.51 \\
\hline $16020329-2$ & MTB-01A & Bulimina marginata* & $0-0.5 \mathrm{~cm}$ & 4 & 13 & -0.51 & 3.19 \\
\hline $16020329-3$ & MTB-01A & Bulimina marginata* & $0-0.5 \mathrm{~cm}$ & 3 & 15 & -0.09 & 2.94 \\
\hline $16020329-4$ & MTB-01A & Bulimina marginata* & $0-0.5 \mathrm{~cm}$ & 3 & 13 & -0.33 & 3.87 \\
\hline $16020330-1$ & MTB-01A & Bulimina marginata & $0.0 .5 \mathrm{~cm}$ & 1 & 29 & -0.22 & 2.77 \\
\hline $16020330-2$ & MTB-01A & Bulimina marginata & $0.0 .5 \mathrm{~cm}$ & 1 & 28 & 0.00 & 2.43 \\
\hline $16020330-3$ & MTB-01A & Bulimina marginata & $0.0 .5 \mathrm{~cm}$ & 1 & 13 & 0.38 & 2.38 \\
\hline $16020330-4$ & MTB-01A & Bulimina marginata & $0.0 .5 \mathrm{~cm}$ & 1 & 15 & 0.22 & 2.50 \\
\hline $16021132-3$ & MTB-01A & Uvigerina hispida* & $0-0.5 \mathrm{~cm}$ & 2 & 12 & -0.16 & 4.10 \\
\hline $16021132-4$ & MTB-01A & Uvigerina hispida* & $0-0.5 \mathrm{~cm}$ & 3 & 12 & -0.11 & 5.18 \\
\hline $16021133-1$ & MTB-01A & Uvigerina hispida & $0-0.5 \mathrm{~cm}$ & 1 & 11 & 0.59 & 5.27 \\
\hline $16021135-1$ & MTB-01A & Hoeglundina elegans & $0-0.5 \mathrm{~cm}$ & 1 & 27 & 1.37 & 2.84 \\
\hline $16021135-2$ & MTB-01A & Hoeglundina elegans & $0-0.5 \mathrm{~cm}$ & 1 & 314 & -1.13 & 2.58 \\
\hline $16021135-3$ & MTB-01A & Hoeglundina elegans & $0-0.5 \mathrm{~cm}$ & 1 & 65 & 1.29 & 3.32 \\
\hline $16021135-4$ & MTB-01A & Hoeglundina elegans & $0-0.5 \mathrm{~cm}$ & 2 & 12 & 1.87 & 4.43 \\
\hline $16021135-5$ & MTB-01A & Hoeglundina elegans & $0-0.5 \mathrm{~cm}$ & 1 & 10 & 2.32 & 4.09 \\
\hline $16021036-1$ & MTB-01A & Melonis barleeanus & $1.5-2 \mathrm{~cm}$ & 1 & 16 & -1.83 & 1.38 \\
\hline $16021036-2$ & MTB-01A & Melonis barleeanus & $1.5-2 \mathrm{~cm}$ & 1 & 18 & -1.71 & 1.73 \\
\hline $16021036-3$ & MTB-01A & Melonis barleeanus & $1.5-2 \mathrm{~cm}$ & 1 & 27 & -1.85 & 1.44 \\
\hline $16021036-4$ & MTB-01A & Melonis barleeanus & $1.5-2 \mathrm{~cm}$ & 1 & 10 & -1.04 & 2.24 \\
\hline $16021036-5$ & MTB-01A & Melonis barleeanus & $1.5-2 \mathrm{~cm}$ & 1 & 27 & -1.94 & 1.45 \\
\hline $16021037-1$ & MTB-01A & Globobulimina barbata & $1.5-4 \mathrm{~cm}$ & 1 & 29 & -1.85 & 1.52 \\
\hline $16021037-2$ & MTB-01A & Globobulimina barbata & $1.5-4 \mathrm{~cm}$ & 1 & 35 & -1.72 & 1.44 \\
\hline $16021037-3$ & MTB-01A & Globobulimina barbata & $1.5-4 \mathrm{~cm}$ & 1 & 30 & -1.66 & 1.85 \\
\hline $16021037-4$ & MTB-01A & Globobulimina barbata & $1.5-4 \mathrm{~cm}$ & 1 & 33 & -2.05 & 2.07 \\
\hline $16021037-5$ & MTB-01A & Globobulimina barbata & $1.5-4 \mathrm{~cm}$ & 1 & 31 & -1.78 & 1.66 \\
\hline $16021038-1$ & MTB-01B & Bulimina marginata* & $0-0.5 \mathrm{~cm}$ & 3 & 12 & -0.01 & 2.77 \\
\hline $16021038-2$ & MTB-01B & Bulimina marginata* & $0-0.5 \mathrm{~cm}$ & 3 & 13 & 0.47 & 4.91 \\
\hline $16021039-1$ & MTB-01B & Bulimina marginata & $0-0.5 \mathrm{~cm}$ & 1 & 41 & -0.15 & 1.61 \\
\hline $16021039-2$ & MTB-01B & Bulimina marginata & $0-0.5 \mathrm{~cm}$ & 1 & 26 & -0.06 & 1.71 \\
\hline $16021039-3$ & MTB-01B & Bulimina marginata & $0-0.5 \mathrm{~cm}$ & 1 & 32 & 0.41 & 2.17 \\
\hline $16021039-4$ & MTB-01B & Bulimina marginata & $0-0.5 \mathrm{~cm}$ & 1 & 27 & 0.26 & 2.39 \\
\hline $16021039-5$ & MTB-01B & Bulimina marginata & $0-0.5 \mathrm{~cm}$ & 1 & 22 & 0.24 & 1.78 \\
\hline $16021041-2$ & MTB-01B & Uvigerina hispida* & $0-0.5 \mathrm{~cm}$ & 4 & 10 & -0.07 & 5.64 \\
\hline $16021042-1$ & MTB-01B & Uvigerina hispida & $0-0.5 \mathrm{~cm}$ & 2 & 15 & -0.07 & 2.77 \\
\hline $16021042-2$ & MTB-01B & Uvigerina hispida & $0-0.5 \mathrm{~cm}$ & 2 & 13 & -0.40 & 2.72 \\
\hline $16021042-3$ & MTB-01B & Uvigerina hispida & $0-0.5 \mathrm{~cm}$ & 2 & 13 & -0.42 & 3.26 \\
\hline $16021042-4$ & MTB-01B & Uvigerina hispida & $0-0.5 \mathrm{~cm}$ & 2 & 17 & -0.54 & 1.82 \\
\hline $16021042-5$ & MTB-01B & Uvigerina hispida & $0-0.5 \mathrm{~cm}$ & 1 & 18 & -0.43 & 2.14 \\
\hline $16013144-1$ & MTB-01B & Hoeglundina elegans & $0-0.5 \mathrm{~cm}$ & 1 & 9 & 2.18 & 4.72 \\
\hline $16013144-2$ & MTB-01B & Hoeglundina elegans & $0-0.5 \mathrm{~cm}$ & 3 & 14 & 1.67 & 3.61 \\
\hline $16013144-4$ & MTB-01B & Hoeglundina elegans & $0-0.5 \mathrm{~cm}$ & 3 & 14 & 1.76 & 2.77 \\
\hline $16013145-2$ & MTB-01B & Melonis barleeanus & $2-3 \mathrm{~cm}$ & 1 & 10 & -1.05 & 2.10 \\
\hline $16013145-3$ & MTB-01B & Melonis barleeanus & $2-3 \mathrm{~cm}$ & 1 & 11 & -1.03 & 2.01 \\
\hline $16013145-4$ & MTB-01B & Melonis barleeanus & $2-3 \mathrm{~cm}$ & 2 & 12 & -1.51 & 2.09 \\
\hline $16013145-5$ & MTB-01B & Melonis barleeanus & $2-3 \mathrm{~cm}$ & 3 & 13 & -0.30 & 2.86 \\
\hline $16013146-1$ & MTB-01B & Globobulimina barbata & $3-5 \mathrm{~cm}$ & 1 & 32 & -1.80 & 2.54 \\
\hline $16013146-2$ & MTB-01B & Globobulimina barbata & $3-5 \mathrm{~cm}$ & 1 & 31 & -2.04 & 1.45 \\
\hline $16013146-3$ & MTB-01B & Globobulimina barbata & $3-5 \mathrm{~cm}$ & 1 & 28 & -1.83 & 2.00 \\
\hline
\end{tabular}


Table 3 (B)

\begin{tabular}{|c|c|c|c|c|c|c|c|}
\hline $1601301-1$ & MTB-07A & Bolivina alata & $0.5-1 \mathrm{~cm}$ & 4 & 11 & -4.03 & 4.63 \\
\hline $1601302-1$ & MTB-07A & Bolivina alata & $1-1.5 \mathrm{~cm}$ & 2 & 11 & -4.90 & 2.61 \\
\hline $1601302-2$ & MTB-07A & Bolivina alata & $1-1.5 \mathrm{~cm}$ & 3 & 12 & -2.84 & 3.05 \\
\hline $1601302-3$ & MTB-07A & Bolivina alata & $1-1.5 \mathrm{~cm}$ & 2 & 11 & -3.87 & 2.24 \\
\hline $1601303-1$ & MTB-07A & Bolivina alata & $1.5-2 \mathrm{~cm}$ & 1 & 12 & -1.11 & 3.30 \\
\hline $1601303-3$ & MTB-07A & Bolivina alata & $1.5-2 \mathrm{~cm}$ & 2 & 12 & -5.19 & 2.91 \\
\hline $1601303-4$ & MTB-07A & Bolivina alata & $1.5-2 \mathrm{~cm}$ & 1 & 15 & -5.32 & 2.58 \\
\hline $1601303-5$ & MTB-07A & Bolivina alata & $1.5-2 \mathrm{~cm}$ & 1 & 12 & -2.57 & 2.94 \\
\hline $1601304-1$ & MTB-07A & Bulimina marginata & $0-0.5 \mathrm{~cm}$ & 1 & 11 & -2.41 & 2.64 \\
\hline $1601304-2$ & MTB-07A & Bulimina marginata & $0-0.5 \mathrm{~cm}$ & 1 & 11 & -1.61 & 2.87 \\
\hline $1601304-4$ & MTB-07A & Bulimina marginata & $0-0.5 \mathrm{~cm}$ & 1 & 9 & -1.40 & 2.46 \\
\hline $1601304-5$ & MTB-07A & Bulimina marginata & $0-0.5 \mathrm{~cm}$ & 2 & 11 & -3.37 & 2.38 \\
\hline $1601305-3$ & MTB-07A & Bulimina marginata* & $0-0.5 \mathrm{~cm}$ & 4 & 10 & -2.40 & 5.29 \\
\hline $1601316-1$ & MTB-07A & Bulimina marginata & $0.5-1 \mathrm{~cm}$ & 2 & 15 & -2.40 & 3.14 \\
\hline $1601316-2$ & MTB-07A & Bulimina marginata & $0.5-1 \mathrm{~cm}$ & 2 & 12 & -0.98 & 4.14 \\
\hline $1601316-3$ & MTB-07A & Bulimina marginata & $0.5-1 \mathrm{~cm}$ & 2 & 16 & -3.43 & 3.30 \\
\hline $1601316-4$ & MTB-07A & Bulimina marginata & $0.5-1 \mathrm{~cm}$ & 2 & 14 & -3.34 & 3.37 \\
\hline $1601316-5$ & MTB-07A & Bulimina marginata & $0.5-1 \mathrm{~cm}$ & 1 & 11 & -3.38 & 2.31 \\
\hline $1601317-1$ & MTB-07A & Bulimina marginata* & $0.5-1 \mathrm{~cm}$ & 5 & 11 & -1.43 & 5.53 \\
\hline $1601318-1$ & MTB-07A & Bulimina marginata & $1-1.5 \mathrm{~cm}$ & 3 & 10 & -1.16 & 3.76 \\
\hline $1601318-3$ & MTB-07A & Bulimina marginata & $1-1.5 \mathrm{~cm}$ & 1 & 11 & -2.54 & 3.08 \\
\hline $1601318-5$ & MTB-07A & Bulimina marginata & $1-1.5 \mathrm{~cm}$ & 1 & 12 & -2.79 & 2.91 \\
\hline $16013110-1$ & MTB-07A & Melonis barleeanus & $0.5-2 \mathrm{~cm}$ & 1 & 20 & -4.53 & 1.62 \\
\hline $16013111-1$ & MTB-07A & Uvigerina hispida & $0-1 \mathrm{~cm}$ & 1 & 9 & -1.20 & 3.00 \\
\hline $16013111-2$ & MTB-07A & Uvigerina hispida & $0-1 \mathrm{~cm}$ & 2 & 11 & -2.44 & 3.12 \\
\hline $16013111-3$ & MTB-07A & Uvigerina hispida & $0-1 \mathrm{~cm}$ & 1 & 16 & -3.71 & 2.03 \\
\hline $16013111-4$ & MTB-07A & Uvigerina hispida & $0-1 \mathrm{~cm}$ & 1 & 25 & -2.88 & 2.74 \\
\hline $16020212-1$ & MTB-07A & Hoeglundina elegans & $0-0.5 \mathrm{~cm}$ & 2 & 13 & -0.11 & 3.26 \\
\hline $16020214-1$ & MTB-07A & Pullenia bulloides & $0.5-1 \mathrm{~cm}$ & 1 & 20 & -6.72 & 2.01 \\
\hline $16020214-2$ & MTB-07A & Pullenia bulloides & $0.5-1 \mathrm{~cm}$ & 1 & 21 & -3.29 & 1.65 \\
\hline $16020214-3$ & MTB-07A & Pullenia bulloides & $0.5-1 \mathrm{~cm}$ & 1 & 24 & -6.21 & 2.14 \\
\hline $16020214-4$ & MTB-07A & Pullenia bulloides & $0.5-1 \mathrm{~cm}$ & 1 & 22 & -3.65 & 2.37 \\
\hline $16020214-5$ & MTB-07A & Pullenia bulloides & $0.5-1 \mathrm{~cm}$ & 1 & 26 & -3.47 & 2.10 \\
\hline $16020215-2$ & MTB-07B & Bolivina alata & $0.5-1 \mathrm{~cm}$ & 1 & 14 & -3.18 & 3.41 \\
\hline $16020215-3$ & MTB-07B & Bolivina alata & $0.5-1 \mathrm{~cm}$ & 2 & 12 & -1.85 & 3.07 \\
\hline $16020215-4$ & MTB-07B & Bolivina alata & $0.5-1 \mathrm{~cm}$ & 1 & 10 & -1.90 & 3.37 \\
\hline $16020215-5$ & MTB-07B & Bolivina alata & $0.5-1 \mathrm{~cm}$ & 2 & 12 & -4.22 & 3.59 \\
\hline $16020216-1$ & MTB-07B & Bolivina alata* & $0-0.5 \mathrm{~cm}$ & 2 & 10 & -2.30 & 4.06 \\
\hline $16020216-2$ & MTB-07B & Bolivina alata* & $0-0.5 \mathrm{~cm}$ & 3 & 10 & -4.03 & 4.42 \\
\hline $16020216-3$ & MTB-07B & Bolivina alata* & $0-0.5 \mathrm{~cm}$ & 3 & 12 & -2.97 & 4.05 \\
\hline $16020117-1$ & MTB-07B & Bolivina alata & $1-1.5 \mathrm{~cm}$ & 1 & 9 & -4.49 & 3.22 \\
\hline $16020117-2$ & MTB-07B & Bolivina alata & $1-1.5 \mathrm{~cm}$ & 2 & 12 & -5.03 & 3.53 \\
\hline $16020117-3$ & MTB-07B & Bolivina alata & $1-1.5 \mathrm{~cm}$ & 1 & 11 & -0.98 & 2.81 \\
\hline $16020117-4$ & MTB-07B & Bolivina alata & $1-1.5 \mathrm{~cm}$ & 2 & 12 & -1.36 & 3.47 \\
\hline $16020118-1$ & MTB-07B & Bulimina marginata & $0-0.5 \mathrm{~cm}$ & 1 & 9 & -2.84 & 3.32 \\
\hline $16020118-2$ & MTB-07B & Bulimina marginata & $0-0.5 \mathrm{~cm}$ & 1 & 13 & -3.27 & 2.84 \\
\hline $16020118-3$ & MTB-07B & Bulimina marginata & $0-0.5 \mathrm{~cm}$ & 1 & 12 & -2.47 & 3.92 \\
\hline $16020118-4$ & MTB-07B & Bulimina marginata & $0-0.5 \mathrm{~cm}$ & 1 & 13 & -0.76 & 3.28 \\
\hline $16020120-1$ & MTB-07B & Bulimina marginata & $0.5-1 \mathrm{~cm}$ & 1 & 23 & -3.00 & 2.42 \\
\hline $16020120-2$ & MTB-07B & Bulimina marginata & $0.5-1 \mathrm{~cm}$ & 1 & 57 & -2.65 & 2.31 \\
\hline $16020120-4$ & MTB-07B & Bulimina marginata & $0.5-1 \mathrm{~cm}$ & 1 & 11 & -3.49 & 2.48 \\
\hline $16020120-5$ & MTB-07B & Bulimina marginata & $0.5-1 \mathrm{~cm}$ & 1 & 14 & -2.99 & 2.08 \\
\hline $16020121-1$ & MTB-07B & Bulimina marginata* & $0.5-1 \mathrm{~cm}$ & 2 & 12 & -3.66 & 1.88 \\
\hline $16020121-2$ & MTB-07B & Bulimina marginata* & $0.5-1 \mathrm{~cm}$ & 2 & 13 & -1.41 & 1.87 \\
\hline $16020121-3$ & MTB-07B & Bulimina marginata* & $0.5-1 \mathrm{~cm}$ & 2 & 10 & -1.31 & 1.85 \\
\hline $16020121-5$ & MTB-07B & Bulimina marginata* & $0.5-1 \mathrm{~cm}$ & 3 & 13 & -2.30 & 2.02 \\
\hline $16020123-2$ & MTB-07B & Melonis barleeanus & $0-1.5 \mathrm{~cm}$ & 1 & 11 & -4.50 & 0.52 \\
\hline $16020125-1$ & MTB-07B & Hoeglundina elegans & $0-0.5 \mathrm{~cm}$ & 4 & 10 & -1.89 & 2.12 \\
\hline $16020225-2$ & MTB-07B & Hoeglundina elegans & $0-0.5 \mathrm{~cm}$ & 1 & 11 & 1.07 & 2.28 \\
\hline $16020226-1$ & MTB-07B & Hoeglundina elegans & $0.5-1 \mathrm{~cm}$ & 1 & 9 & -1.51 & 2.04 \\
\hline $16020226-2$ & MTB-07B & Hoeglundina elegans & $0.5-1 \mathrm{~cm}$ & 2 & 10 & 1.15 & 2.39 \\
\hline $16020226-3$ & MTB-07B & Hoeglundina elegans & $0.5-1 \mathrm{~cm}$ & 1 & 31 & -1.08 & 2.93 \\
\hline $16020226-4$ & MTB-07B & Hoeglundina elegans & $0.5-1 \mathrm{~cm}$ & 2 & 10 & -1.17 & 2.59 \\
\hline $16020226-5$ & MTB-07B & Hoeglundina elegans & $0.5-1 \mathrm{~cm}$ & 2 & 14 & -0.94 & 2.33 \\
\hline $16020227-1$ & MTB-07B & Bulimina inflata & $0.5-1 \mathrm{~cm}$ & 2 & 11 & -5.56 & 1.50 \\
\hline $16020227-3$ & MTB-07B & Bulimina inflata & $0.5-1 \mathrm{~cm}$ & 3 & 11 & -5.14 & 1.61 \\
\hline $16020328-1$ & MTB-07B & Pullenia bulloides & $0.5-1 \mathrm{~cm}$ & 1 & 28 & -3.90 & 1.92 \\
\hline $16020328-2$ & MTB-07B & Pullenia bulloides & $0.5-1 \mathrm{~cm}$ & 1 & 21 & -3.37 & 1.80 \\
\hline $16020328-3$ & MTB-07B & Pullenia bulloides & $0.5-1 \mathrm{~cm}$ & 1 & 30 & -3.86 & 2.09 \\
\hline $16020328-4$ & MTB-07B & Pullenia bulloides & $0.5-1 \mathrm{~cm}$ & 1 & 26 & -3.05 & 2.00 \\
\hline $16020328-5$ & MTB-07B & Pullenia bulloides & $0.5-1 \mathrm{~cm}$ & 1 & 22 & -3.90 & 1.98 \\
\hline
\end{tabular}



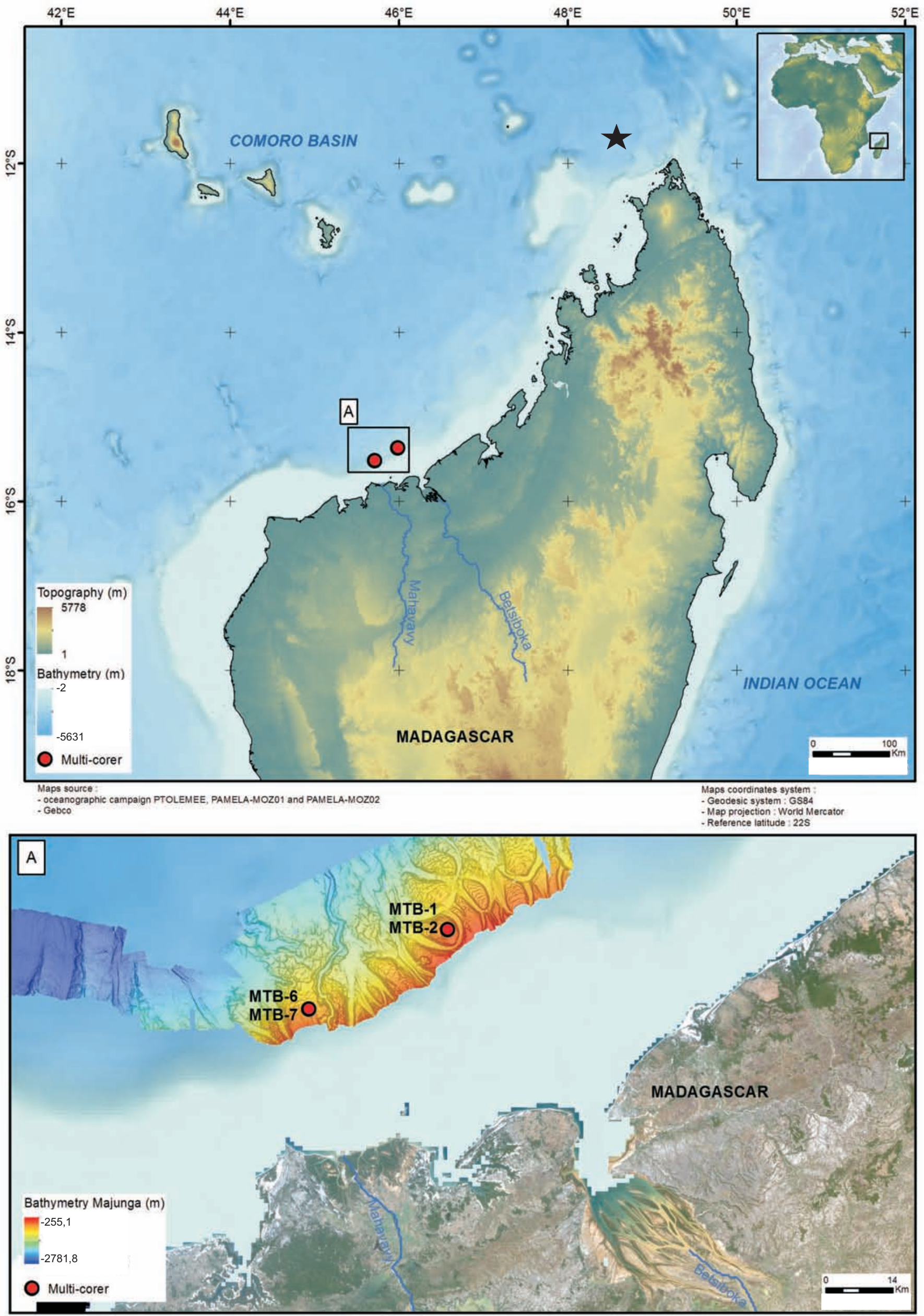
Figure 2
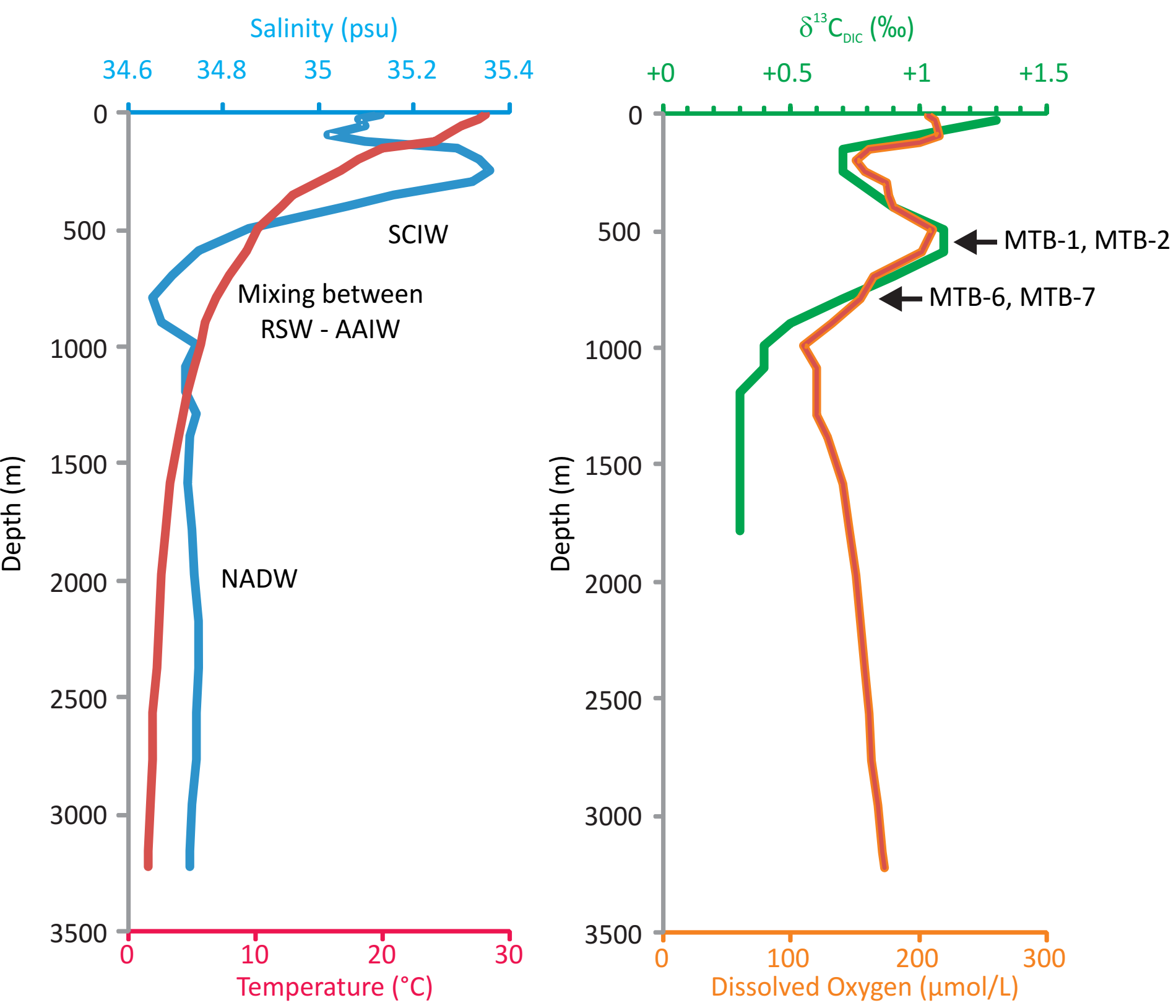
Figure 3

\section{Mahavavy slope station}

\section{MTB-7A}
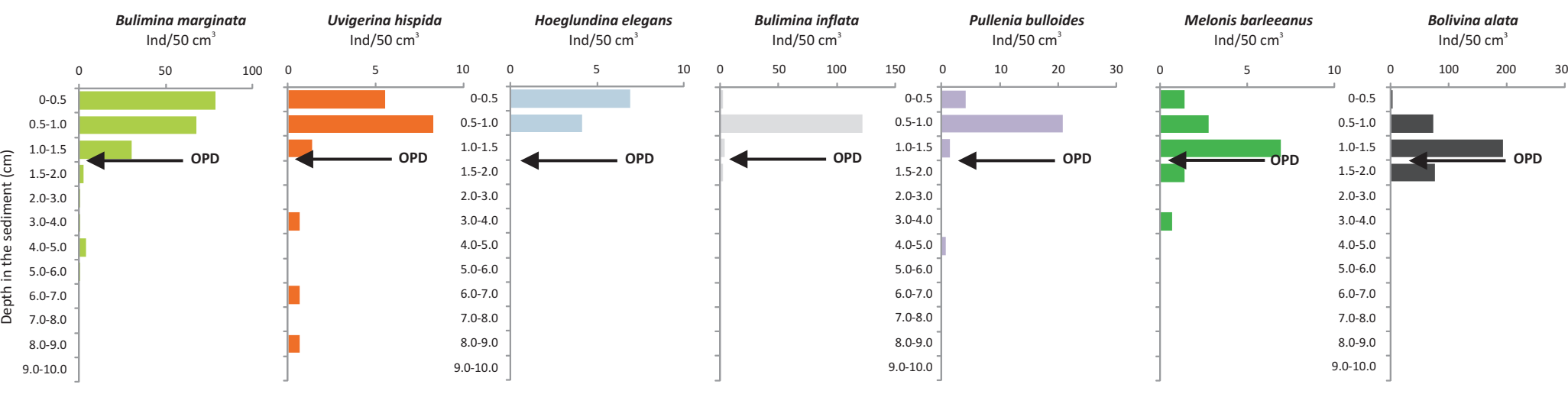

\section{MTB-7B}

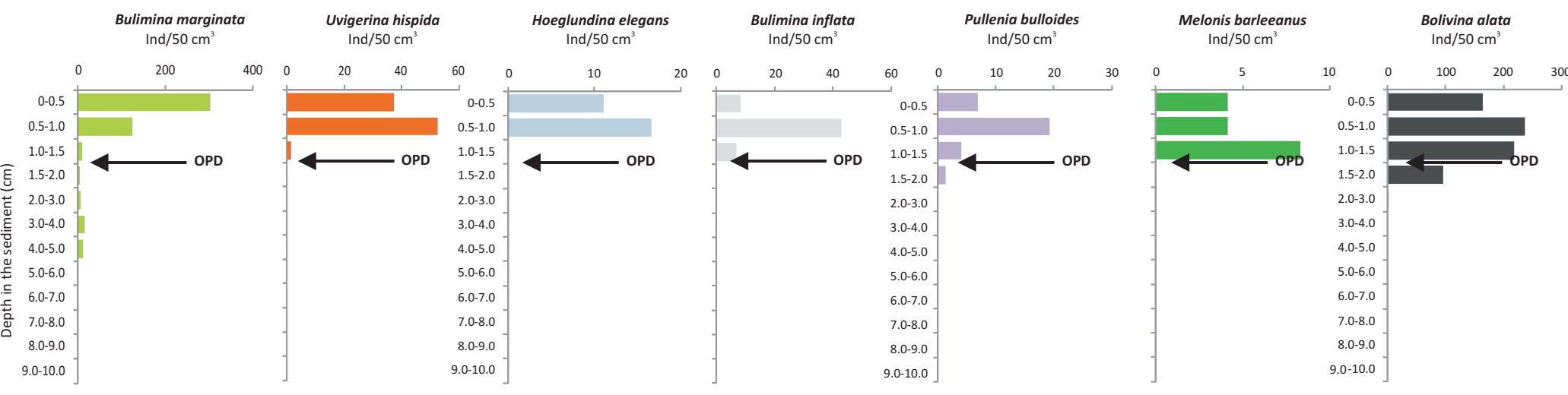




\section{Betsiboka slope station}

MTB-1A \& MTB-1B

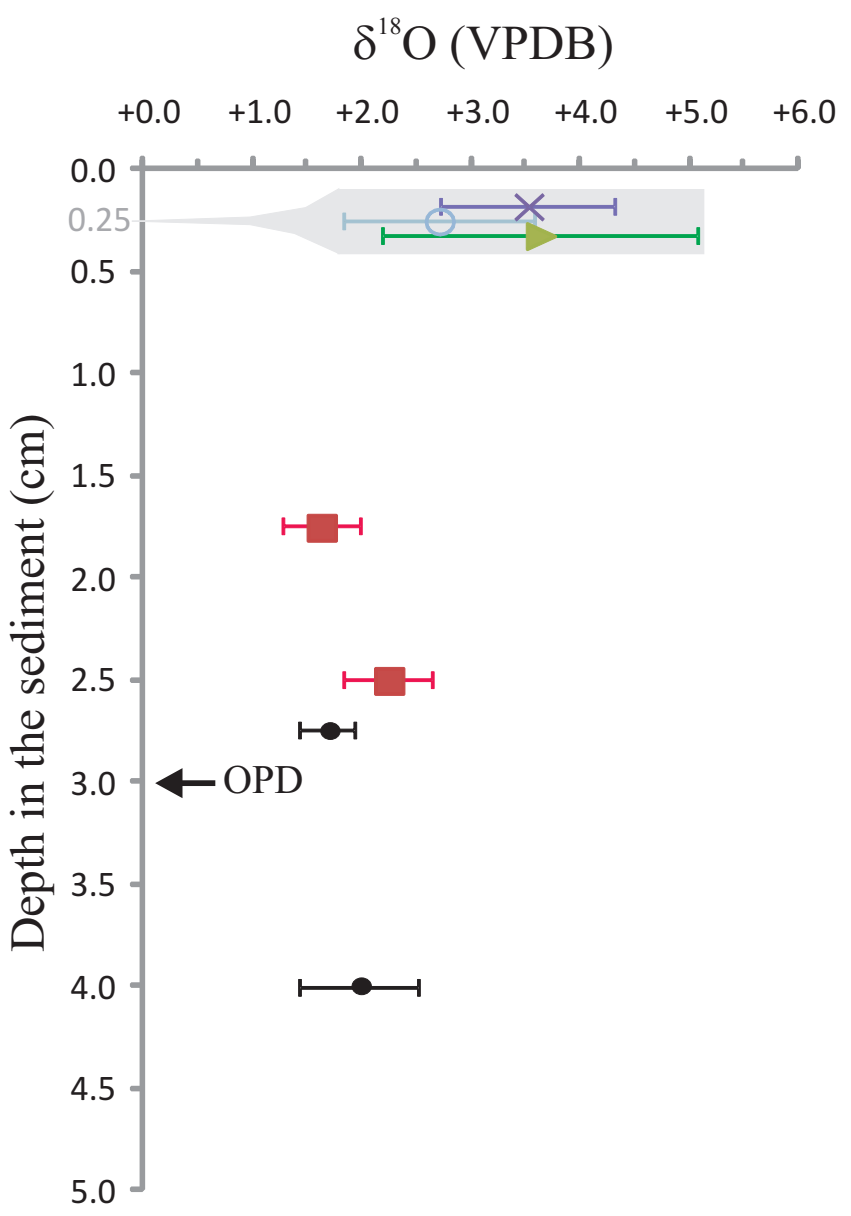

MTB-1A \& MTB-1B

$\delta^{13} \mathrm{C}(\mathrm{VPDB})$

$\begin{array}{lllllllllllll}-7 & -6 & -5 & -4 & -3 & -2 & -1 & 0 & +1 & +2 & +3 & +4 & +5\end{array}$

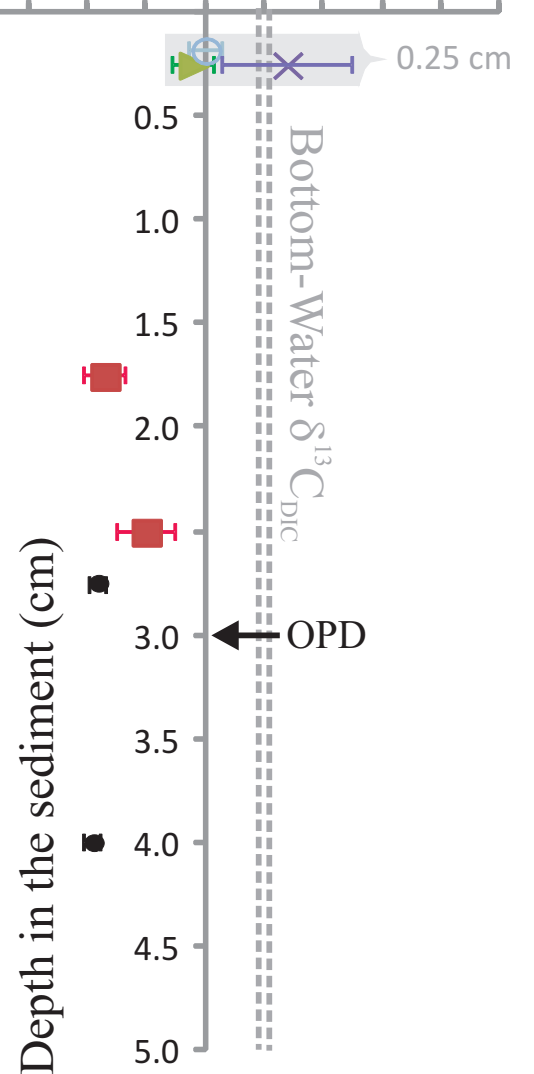

Mahavavy slope station

MTB-7A \& MTB-7B

$\delta^{18} \mathrm{O}(\mathrm{VPDB})$

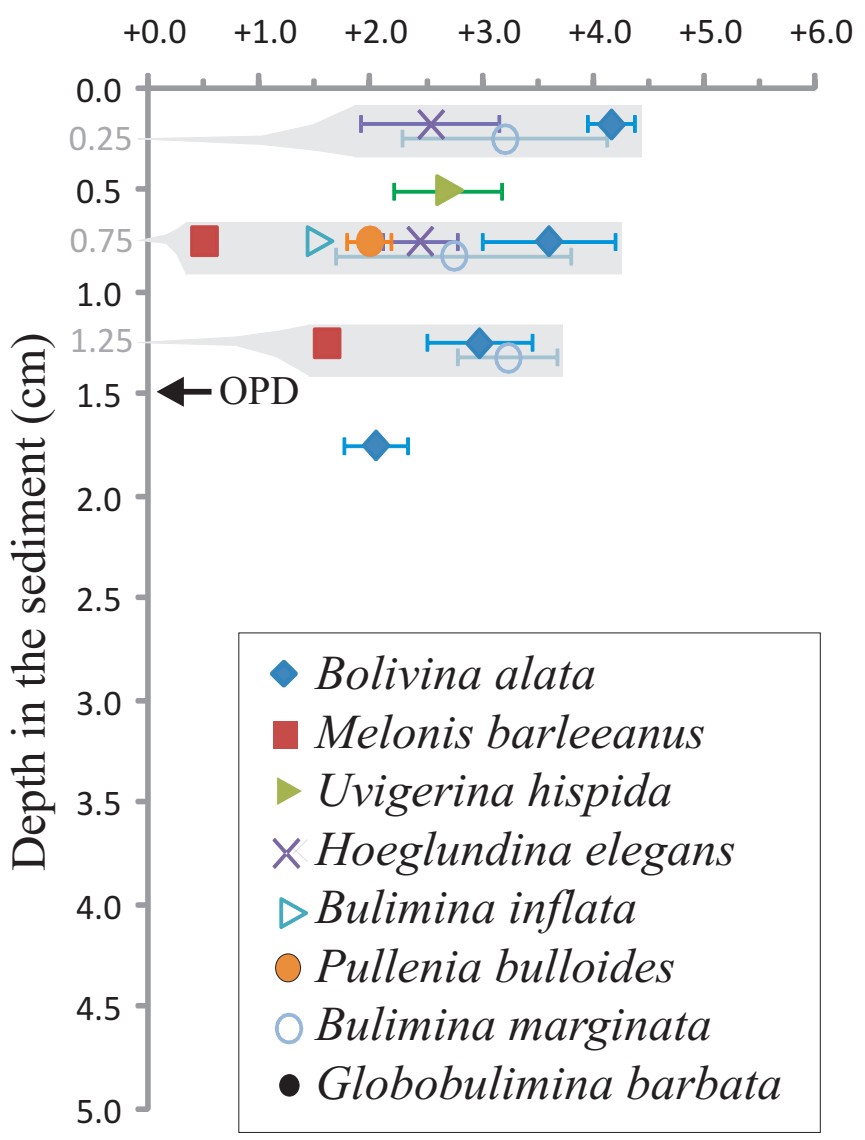

MTB-7A \& MTB-7B

$\delta^{13} \mathrm{C}(\mathrm{VPDB})$

$\begin{array}{lllllllllllll}-7 & -6 & -5 & -4 & -3 & -2 & -1 & 0 & +1 & +2 & +3 & +4 & +5\end{array}$

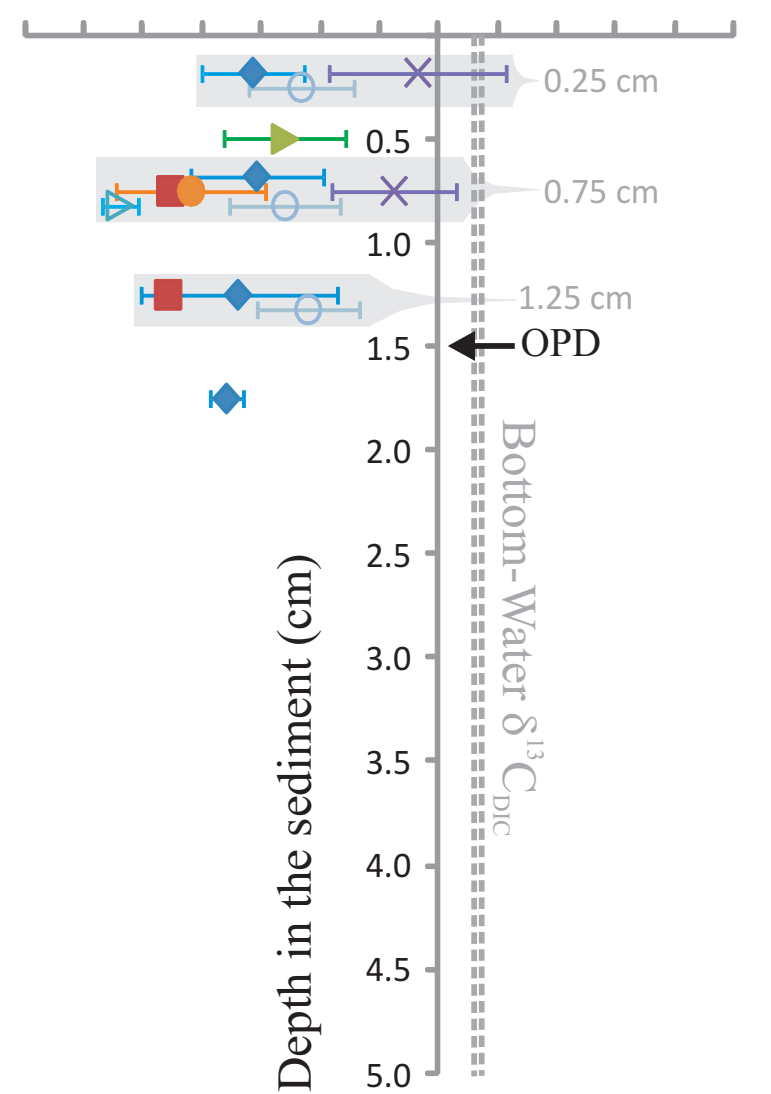


Figure 5

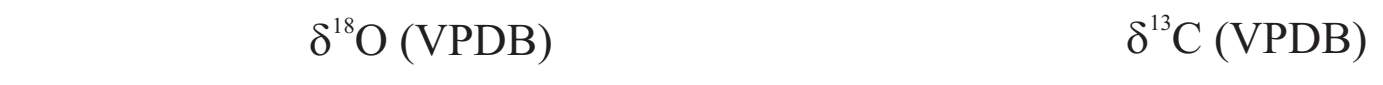

$\begin{array}{llllllllllllllllllll}0 & 1 & 2 & 3 & 4 & 5 & 6 & -7 & -6 & -5 & -4 & -3 & -2 & -1 & 0 & 1 & 2 & 3\end{array}$

Hoeglundina elegans (VSI)

Uvigerina hispida (SI)
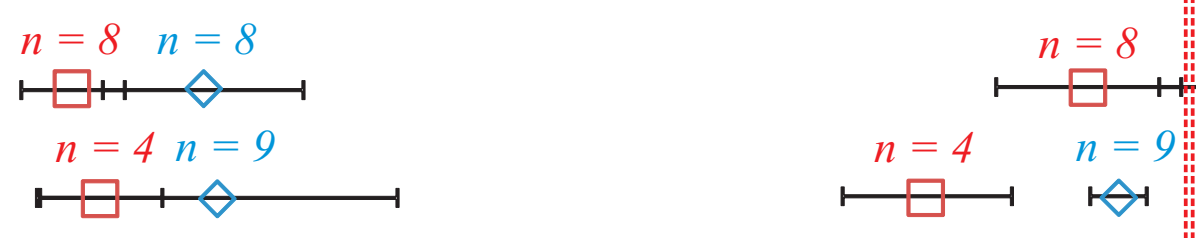

Bulimina marginata $(\mathrm{SI})$

$$
n=15 n=26
$$$$
\begin{array}{cc}
n=26 & n=15 \\
\mapsto & \mapsto 1
\end{array}
$$

Bolivina alata (II)

$$
n=19
$$

Bulimina inflata (II)

$$
n=2
$$

$\Theta$

$$
\begin{gathered}
n=10 \\
\text { 曰日 }
\end{gathered}
$$

Melonis barleeanus (II)

$$
n=2 n=9
$$

Globobulimina barbata

$$
\text { (DI) } \quad \begin{aligned}
& n=5 \\
& \mapsto \diamond-1
\end{aligned}
$$

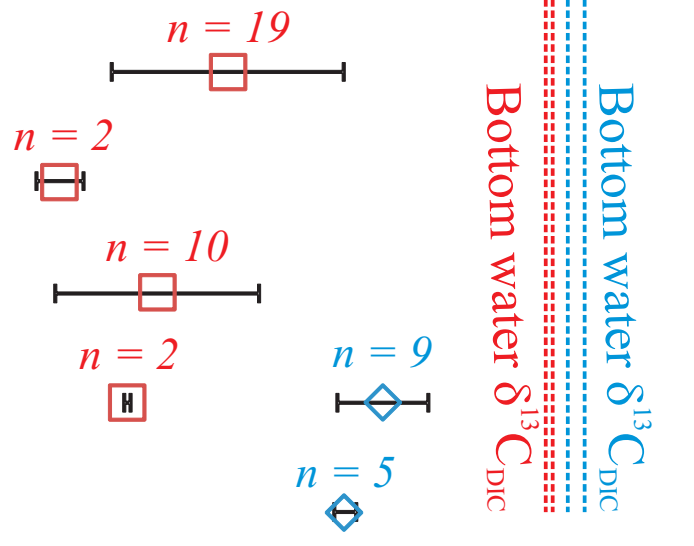

Betsiboka slope station (MTB-1A \& MTB-1B)

Mahavavy slope station (MTB-7A \& MTB-7B) 


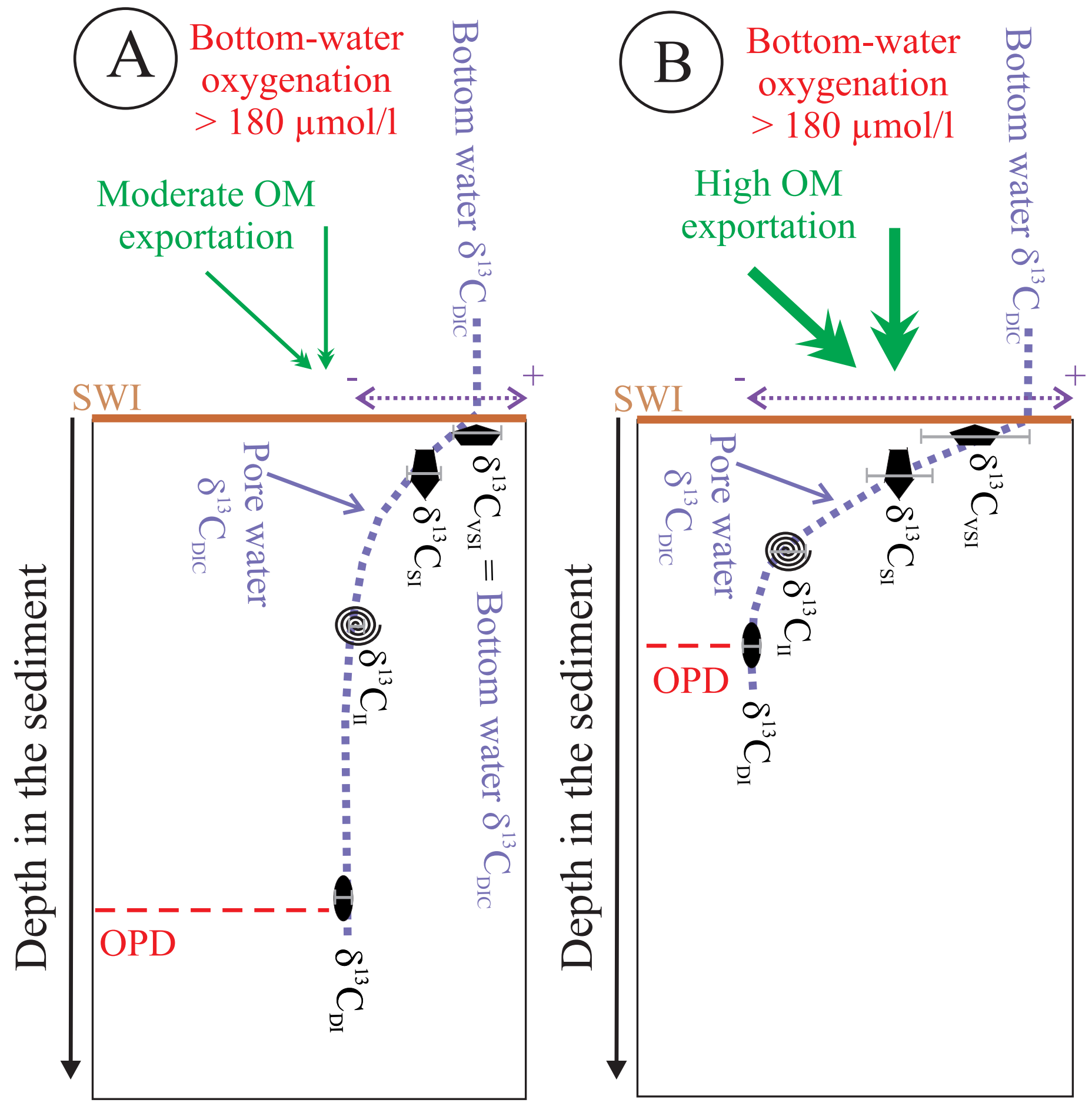

- Very Shallow Infaunal species (Hoeglundina spp.)

- Shallow Infaunal species (Uvigerina spp.)

(Q) Intermediate Infaunal species (Melonis spp.)

Deep Infaunal species (Globobulimina spp.) 